\title{
THE SMOKER'S PARADOX DURING THE COVID-19 PANDEMIC? THE INFLUENCE OF SMOKING AND VAPING ON THE INCIDENCE AND COURSE OF SARS-CoV-2 VIRUS INFECTION AS WELL AS POSSIBILITY OF USING NICOTINE IN THE TREATMENT OF COVID-19 - REVIEW OF THE LITERATURE
}

\author{
PARADOKS PALACZA W DOBIE PANDEMII COVID-19? \\ WPŁYW PALENIA PAPIEROSÓW TRADYCYJNYCH I ELEKTRONICZNYCH NA \\ ZACHOROWALNOŚĆ I PRZEBIEG ZAKAŻENIA WIRUSEM SARS-CoV-2 ORAZ \\ MOŻLIWOŚCI WYKORZYSTANIA NIKOTYNY W LECZENIU COVID-19 \\ - PRZEGLĄD LITERATURY
}

\begin{abstract}
${ }^{1}$ Medical University of Lublin, Students' Scientific Association of Chair and Department of Epidemiology and Clinical Research Methodology

Uniwersytet Medyczny w Lublinie, Studenckie Koło Naukowe przy Katedrze i Zakładzie

Epidemiologii i Metodologii Badań Klinicznych

${ }^{2}$ Medical University of Lublin, Chair of Rehabilitation, Physiotherapy and Balneotherapy,

Department of Rehabilitation and Physiotherapy,

Uniwersytet Medyczny w Lublinie, Katedra Rehabilitacji, Fizjoterapii i Balneoterapii, Zakład Rehabilitacji i Fizjoterapii,

${ }^{3}$ Medical University of Lublin, Chair and Department of Epidemiology and Clinical Research Methodology Uniwersytet Medyczny w Lublinie, Katedra i Zakład Epidemiologii i Metodologii Badań Klinicznych
\end{abstract}

\section{ABSTRACT}

\begin{abstract}
AIM OF THE STUDY. The study aims to present the current state of knowledge on the impact of traditional cigarettes and the nicotine contained in them on the incidence and course of SARS-CoV-2 infection. Moreover, we decided to exhibit the possibility of using this substance to treat COVID-19 infections.
\end{abstract}

MATERIAL AND METHODS. The latest available scientific publications were reviewed until November 14, 2020, from the PubMed platform.

RESULTS. Nicotine is a cholinergic agonist and pro-inflammatory cytokines inhibitor. Some authors present that smoking and nicotine reduce the amount of the ACE2 receptors which are used by the novel coronavirus to enter cells, while others claim that ACE2 receptors are upregulated in smokers. Moreover, the interaction of SARS-CoV-2 with nAChR is suspected of dysregulation of the nicotinic cholinergic system, which is associated with the pathophysiology of COVID-19. Due to the harmfulness of cigarettes, a high frequency of smokers is suspected among people suffering from COVID-19. However, some studies report that the number of current smokers hospitalized for SARS-CoV-2 infection is lower than expected, considering the prevalence of smoking in individual countries. Nicotine could restore the impaired function of the nicotine cholinergic system and possibly mitigate the cytokine storm.

CONCLUSIONS. There is no clear attitude regarding the impact of smoking on the new coronavirus infection now. Researchers do not recommend smoking as a tool to combat the pandemic and show the importance of fighting addiction to reduce the adverse health effects of smoking. Both the relationship between cigarettes and the morbidity and severity of COVID-19, as well as the possibility of using nicotine in the treatment of the disease, require further analysis.

Keywords: nicotine, smoking, COVID-19, SARS-CoV-2 


\section{STRESZCZENIE}

CEL. Celem pracy jest przedstawienie aktualnego stanu wiedzy na temat wpływu papierosów i zawartej w nich nikotyny na zachorowalność i przebieg zakażenia wirusem SARS-CoV-2 oraz ukazanie możliwości wykorzystania tej substancji do leczenia COVID-19.

MATERIAL I METODY. Dokonano przeglądu najnowszych publikacji naukowych do dnia 14.11.2020, wykorzystując w tym celu platformę PubMed.

WYNIKI. Nikotyna jest agonistą cholinergicznym oraz inhibitorem cytokin prozapalnych. Część autorów ukazuje, że palenie i nikotyna zmniejszają ilość receptorów ACE2, które są wykorzystywane przez nowego koronawirusa do wnikania w komórki, inni z kolei twierdzą, że palacze mają podwyższoną ekspresję tych receptorów. Ponadto interakcja SARS-CoV-2 z nAChR podejrzewana jest o rozregulowanie nikotynowego układu cholinergicznego, który jest powiązany z patofizjologią COVID-19. W związku z dużą szkodliwością papierosów podejrzewa się częstsze występowanie palaczy pośród osób chorych na COVID-19. W części badań podano jednak, że liczba obecnych palaczy hospitalizowanych z powodu infekcji wirusem SARS-CoV-2 jest niższa niż oczekiwano, biorąc pod uwagę rozpowszechnienie palenia w poszczególnych krajach. Nikotyna potencjalnie mogłaby zostać wykorzystana do walki z epidemią wirusa SARS-CoV-2, może ona przywrócić upośledzoną funkcję nikotynowego cholinergicznego systemu oraz prawdopodobnie złagodzić burzę cytokin.

WNIOSKI. W chwili obecnej nie ma jednoznacznego stanowiska odnośnie wpływu palenia na zakażenie nowym koronawirusem. Badacze zgodnie nie zalecają palenia jako narzędzia do walki z pandemią i ukazują istotę walki z nałogiem w celu zmniejszenia niepożądanych skutków zdrowotnych palenia. Zarówno zależność między papierosami a zachorowalnością i ciężkością przebiegu COVID-19, jak i możliwości wykorzystania nikotyny w leczeniu nowej choroby, wymagają dalszych pogłębionych analiz.

Słowa kluczowe: nikotyna, palenie, COVID-19, SARS-CoV-2

\section{INTRODUCTION}

Tobacco smoking is very common in the world nowadays. The substances contained in cigarettes increase the susceptibility to cancer diseases, respiratory system diseases (chronic obstructive pulmonary disease, tuberculosis), cardiovascular diseases (myocardial infarction, stroke), and neurological diseases (multiple sclerosis, Alzheimer's disease) $(1,2,3)$. The outbreak of the novel SARS$\mathrm{CoV}-2$ coronavirus spreading by droplet transmission has prompted scientists to investigate the effects of cigarette smoking on morbidity and mortality because of COVID-19. It may be surprising that the results of some studies indicate a lower number of smoking patients with COVID-19 in hospitals compared to the general population (4-12). It was suspected that cigarettes, and especially the nicotine contained in them, may have a protective effect against SARS$\mathrm{CoV}-2$ infection. Other studies emphasize the negative impact of inhaling tobacco smoke on the respiratory system, on infection with the novel coronavirus, and more severe course of the disease $(5,12-17)$.

Cigarette smoke lowers the immunity of the respiratory system by causing inflammation and peribronchial fibrosis, impaired mucociliary clearance, and disruption of the respiratory epithelium, which promotes both viral and bacterial infections (4). The possible mechanisms as a result of which smoking may be protective in COVID-19 include the anti-

\section{WSTĘP}

Palenie tytoniu jest współcześnie bardzo rozpowszechnione na świecie. Substancje zawarte w papierosach zwiększają podatność na choroby: nowotworowe, układu oddechowego (przewlekła obturacyjna choroba płuc, gruźlica), układu krążenia (zawał mięśnia sercowego, udar) oraz neurologiczne (stwardnienie rozsiane, choroba Alzheimera) (1,2,3). Wybuch pandemii nowego koronawirusa SARS-CoV-2 rozprzestrzeniającego się drogą kropelkową skłonił naukowców do zbadania wpływu palenia papierosów na zachorowalność i śmiertelność z powodu COVID-19. Zaskakujący może okazać się fakt, że wyniki części badań wskazują na zmniejszoną liczbę palących pacjentów chorych na COVID-19 w szpitalach w stosunku do populacji ogólnej (4-12). Zaczęto więc podejrzewać, że papierosy, a w szczególności zawarta w nich nikotyna, może mieć efekt ochronny przed infekcją wirusem SARS-CoV-2. Inne badania podkreślają negatywny wpływ wdychania dymu tytoniowego na układ oddechowy, na infekcję nowym koronawirusem i jej cięższy przebieg $(5,12-17)$.

Dym papierosowy obniża odporność układu oddechowego przez wywoływanie zapalenia i zwłóknienia okołooskrzelowego, upośledzenie klirensu śluzowo-rzęskowego oraz przerwanie ciągłości nabłonka oddechowego, co sprzyja zarówno wirusowym, jak i bakteryjnym infekcjom (4). Prawdopodobne mechanizmy, w wyniku których palenie może działać ochronnie w COVID-19, obejmują przeciwzapalne działanie ni- 
inflammatory effects of nicotine, a decreased immune response in smokers, a reduction in the risk of a cytokine storm, and an increased level of nitric oxide in the airways, which may inhibit SARS-CoV-2 replication and its entry into cells (18). Authors of some research suggest that nicotine down-regulates the receptor for the enzyme that encodes angiotensin 2 (ACE2), which is used by the coronavirus to enter epithelial cells (4). Other research, however, informs about an increased expression of genes and receptors in the respiratory tract and oral cavity epithelium in current smokers, thus exposing them to a higher risk of infection with SARS-CoV-2 virus $(4,5)$. Can nicotine protect the body against infection with the novel coronavirus, or does it increase the risk of infection?

\section{THE AIM OF THE STUDY}

The aim of the study is to present the current state of knowledge on the impact of traditional and electronic cigarettes and the nicotine contained in them on the incidence and course of SARS-CoV-2 infection, as well as to show the possibility of using this substance for the treatment of COVID-19 infections.

\section{MATERIAL AND METHODS}

A review of the latest literature until 14 November 2020 has been made. The literature review was carried out using materials available on the PubMed platform with the use of the following keywords: "nicotine", "smoking", "COVID-19", "SARS-CoV-2". Studies published in English and available as full-text publications were included in the review. Original and review studies were referred to, while studies with an annotation as "preprint" and comments were excluded. There were included 28 studies for further analysis after the unanimous assessment of the usefulness of the article by two authors (after reading the abstracts) (Fig. 1).

\section{RESULTS}

\section{Mechanisms of the influence of nicotine on the human body in the context of SARS-CoV-2 infection}

Nicotine is a cholinergic agonist and an inhibitor of pro-inflammatory cytokines, and its effect is the activation of nicotinic acetylcholine receptors - $\alpha 7$ nAChRs in the cholinergic anti-inflammatory pathway $(19,20,21)$. Nicotine inhibits tumor necrosis factor (TNF), interleukins IL-1, IL-6, and the high-mobility group protein B1 (HMGB1), without affecting antiinflammatory cytokines such as IL-10 (3, 20, 21). Patients with COVID-19 may experience a significant accumulation of immune cells in the lungs due to kotyny, osłabienie odpowiedzi immunologicznej u palaczy, zmniejszające ryzyko burzy cytokinowej oraz zwiększony poziom tlenku azotu w drogach oddechowych, mogący hamować replikację SARS-CoV-2 i jego wejście do komórek (18). Autorzy części badań sugerują, że nikotyna reguluje w dół receptor enzymu kodującego angiotensynę 2 (ACE2), który jest używany przez koronawirusa podczas wnikania do komórek nabłonka (4). Inne prace mówią natomiast o podwyższonej ekspresji genów i receptorów $\mathrm{w}$ drogach oddechowych oraz nabłonku jamy ustnej u obecnych palaczy, narażając ich w ten sposób na wyższe ryzyko infekcji wirusem SARS-CoV-2 (4,5). Czy zatem nikotyna może chronić organizm przed infekcją nowym koronawirusem, czy może jednak zwiększa ryzyko zakażenia?

\section{CEL PRACY}

Celem pracy jest przedstawienie aktualnego stanu wiedzy na temat wpływu papierosów tradycyjnych i elektronicznych oraz zawartej w nich nikotyny na zachorowalność i przebieg zakażenia wirusem SARSCoV-2, a także ukazanie możliwości wykorzystania tej substancji do leczenia zakażeń COVID-19.

\section{MATERIAŁ I METODY}

Dokonano przeglądu najnowszych publikacji naukowych, korzystając z materiałów dostępnych na platformie PubMed. Przeglądu literatury dokonano w dniu 14.11.2020 roku przy użyciu następujących słów kluczowych: "nicotine", "smoking", "COVID-19", "SARS-CoV-2". Do przeglądu włączono prace opublikowane w języku angielskim i dostępne jako publikacje pełnotekstowe. Odniesiono się do prac oryginalnych i przeglądowych, natomiast wykluczono prace $\mathrm{z}$ adnotacją jako "preprint" oraz komentarze. Po przeczytaniu abstraktów przez dwóch autorów i jednomyślnej ocenie przydatności artykułu do dalszej analizy, włączono do przeglądu 28 prac (Ryc. 1).

\section{WYNIKI}

\section{Mechanizmy wpływu nikotyny na organizm czło- wieka w kontekście zakażenia SARS-CoV-2}

Nikotyna jest agonistą cholinergicznym i inhibitorem cytokin prozapalnych, a efektem jej działania jest aktywacja nikotynowych receptorów acetylocholiny a7-nAChRs w cholinergicznym przeciwzapalnym szlaku $(19,20,21)$. Nikotyna hamuje czynnik martwicy nowotworów (TNF), interleukiny IL-1, IL-6 i białko grupy 1 o wysokiej ruchliwości (HMGB1), nie wpływając natomiast na cytokiny przeciwzapalne, takie jak IL-10 $(3,20,21)$. U pacjentów z COVID-19 może dochodzić do znacznej akumulacji komórek układu odpornościowe- 


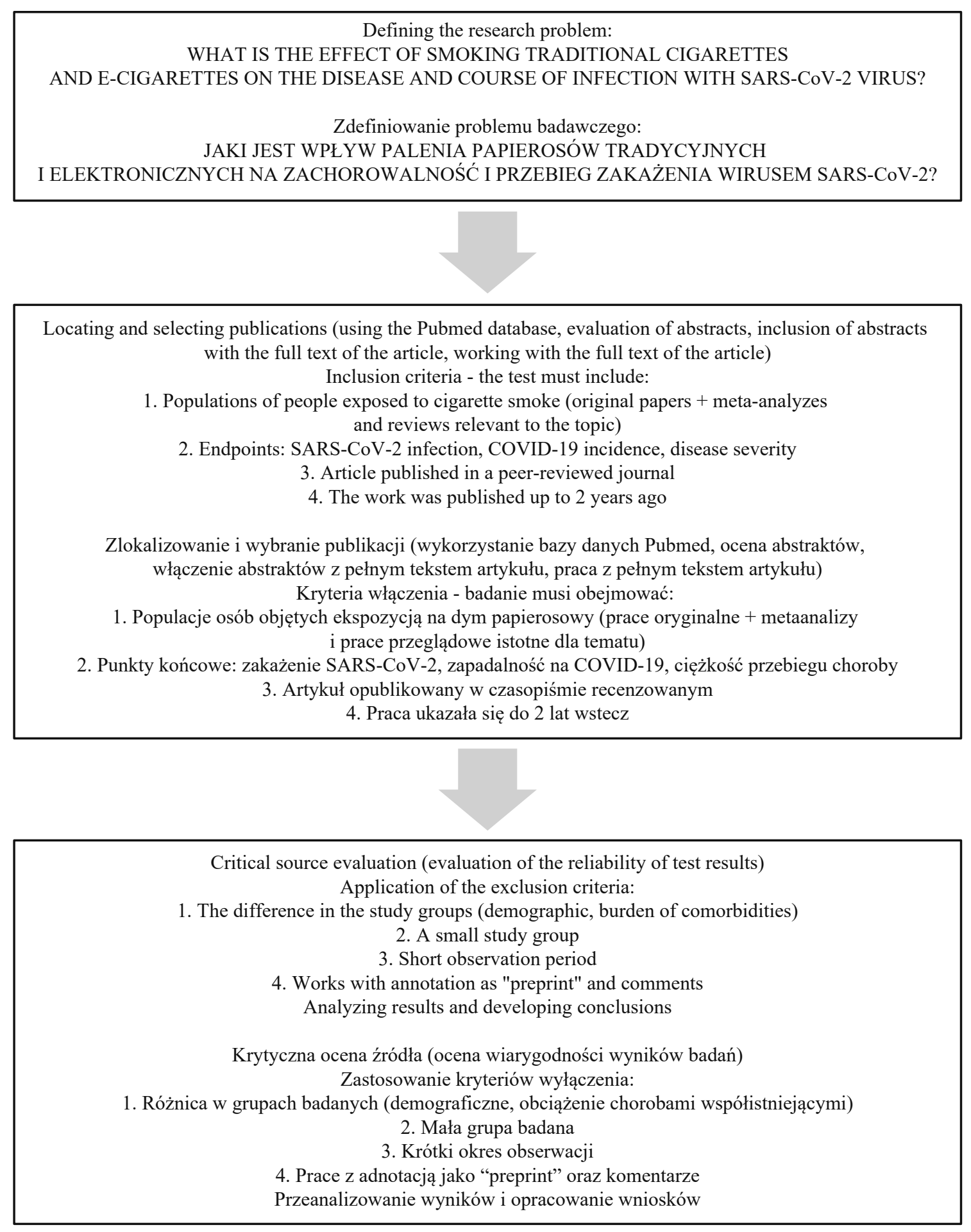

Fig. 1. The steps of work with the source material, inclusion and exclusion criteria for scientific papers from the review Ryc. 1. Etapy pracy z materiałem źródłowym, kryteria włączenia i wyłączenia prac naukowych z przeglądu

the overproduction of pro-inflammatory cytokines known as a cytokine storm, ultimately damaging the lung architecture and contributing to further serious complications. Smoking, on the other hand, increases the inflammatory reaction associated with the COVID-19 response (5).

The SARS-CoV-2 virus enters the cell via the angiotensin-converting enzyme type 2 (ACE2) membrane receptors, which are recognized by the go w płucach z powodu nadmiernej produkcji cytokin prozapalnych zwanej burzą cytokinową, co ostatecznie uszkadza architekturę płuc i przyczynia się do dalszych poważnych komplikacji. Palenie natomiast zwiększa reakcję zapalną związaną z odpowiedzią na COVID-19 (5).

Wirus SARS-CoV-2 dostaje się do komórki za pomocą receptorów błonowych enzymu konwertującego angiotensynę typu 2 (ACE2), rozpoznawanych przez 
viral spike protein (S-glycoprotein). The binding of the virus via the S protein to the ACE2 surface protein protects it from the immune system, allowing infection and further spreading at the same time (5). Research into the link between smoking and ACE2 differs in results, and this suggestion remains unproven. Studies published before the COVID-19 pandemic show that smoking and nicotine reduce the amount of ACE2 receptors, and more recent studies suggest that smokers have an increased expression of ACE2 in the airways $(1,22,23)$. Nicotine may increase the activity of the angiotensin-converting enzyme and inhibit the compensatory axis of the ACE2/ANG-(17) receptor, thus contributing to cardiovascular and pulmonary diseases $(5,20)$. Increased ACE2 expression in smokers' lungs may be the result of the smokinginduced proliferation of secretory cells $(20,23)$. Smith and co-authors estimated that age and gender did not significantly affect lung ACE2 levels in both rodents and humans. Therefore, it is unlikely that the increased incidence of COVID-19 in men and older patients is due to differences in the baseline level of ACE2 expression in the lungs (23). Voinsky and Gurwitz evaluated data from two independent genome-wide NCBI GEO RNA expression files (GSE7894 and GSE994) derived from bronchial epithelial cells in current smokers and never smokers. People from both groups presented very similar levels of messenger RNA encoding information from the $A C E 2$ gene, as well as the TMPRSS2 gene (transmembrane protease, serine 2 initiating SARS-CoV-2 entry into the cell) and the ADAM17 gene (a disintegrin and metalloprotease 17, protease involved in the cleavage and shedding of the ACE2 membrane). The expression level of TMPRSS4, similar in function to TMPRSS2, was increased in bronchial epithelial cells of current smokers compared to those who had never smoked. Elevated levels of TMPRSS4 in the bronchi of smokers may put them at greater risk of SARS-CoV-2 infection (22). Elevated TPMRSS4 expression in smokers' lung epithelial cells may result from chronic exposure to nicotine, acetaldehyde, and tar, resulting in bronchial oxidative stress and inflammation. Serine protease inhibitors that can inhibit TMPRSS2 and TMPRSS4 are considered in COVID-19 therapy (22). Similar conclusions were reached by Chakladar and co-authors whose analysis of data from sequencing of lung and oral epithelial samples obtained from The Cancer Genome Atlas (TCGA) showed that the levels of ACE2 and TMPRSS2 proteins were increased in samples from the epithelial tissue of the lung and mouth of smokers. Moreover, it has been found that the androgen receptor increases the expression of TMPRSS2. Increased activity of the androgen signaling pathway in combination with increased ACE2 expression may be a potential białko wypustowe wirusa (glikoproteinę spike - S). Związanie wirusa za pomocą białka $\mathrm{S}$ z białkiem powierzchniowym ACE2 chroni go przed układem immunologicznym, umożliwiając zarazem infekcję i dalsze rozprzestrzenianie się (5). Badania na temat powiązania palenia i ACE2 różnią się wynikami, a sugestia ta pozostaje niesprawdzona. Prace opublikowane przed pandemią COVID-19 ukazują, że palenie i nikotyna zmniejszają ilość receptorów ACE2, a nowsze badania sugerują, że palacze mają podwyższoną ekspresję ACE2 w drogach oddechowych $(1,22,23)$. Nikotyna może zwiększać aktywność enzymu konwertującego angiotensynę i hamować kompensacyjną oś receptora ACE2/ANG-(1-7), a tym samym przyczyniać się do chorób układu krążenia i płuc $(5,20)$. Zwiększona ekspresja ACE2 w płucach palaczy może być skutkiem wywołanego paleniem rozrostu komórek wydzielniczych $(20,23)$. Smith i współautorzy ocenili, że na poziom ACE2 w płucach zarówno u gryzoni, jak i u ludzi nie ma dużego wpływu wiek ani płeć. Jest więc mało prawdopodobne, aby zwiększona zachorowalność mężczyzn i starszych pacjentów na COVID-19 wynikała z różnic w podstawowym poziomie ekspresji ACE2 w płucach (23). Voinsky i Gurwitz ocenili dane z dwóch niezależnych plików ekspresji RNA całego genomu NCBI GEO (GSE7894 i GSE994), pochodzące z komórek nabłonka oskrzeli osób obecnie palących i tych, które nigdy nie paliły. Osoby z obu grup prezentowały bardzo zbliżone poziomy matrycowego RNA kodującego informację z genu ACE2, jak również genu TMPRSS2 (transmembranowej proteazy serynowej typu 2 inicjującej wejście SARS-CoV-2 do komórki) oraz genu ADAM17 (proteazy zaangażowanej $\mathrm{w}$ rozszczepienie i złuszczanie błony ACE2). Poziom ekspresji TMPRSS4, o podobnej funkcji do TMPRSS2, był podwyższony w komórkach nabłonka oskrzeli u obecnych palaczy w porównaniu z osobami, które nigdy nie paliły. Podwyższone poziomy TMPRSS4 w oskrzelach u palaczy mogą narazić ich na większe ryzyko zakażenia SARS-CoV-2 (22). Podwyższona ekspresja TPMRSS4 w komórkach nabłonka płuc palaczy może wynikać z przewlekłego narażenia na nikotynę, aldehyd octowy i substancje smoliste, co skutkuje stresem oksydacyjnym w oskrzelach i stanem zapalnym. Inhibitory proteazy serynowej mogące hamować TMPRSS2 i TMPRSS4 są rozważane w terapii COVID-19 (22). Do podobnych wniosków doszli Chakladar i współautorzy, których analiza danych z sekwencjonowania próbek nabłonka płuc i jamy ustnej uzyskanych z The Cancer Genome Atlas (TCGA) wykazała, że poziomy białek ACE2 i TMPRSS2 były podwyższone $\mathrm{w}$ próbkach $\mathrm{z}$ tkanki nabłonkowej płuc i jamy ustnej palaczy. Stwierdzono ponadto, że receptor androgenowy zwiększa ekspresję TMPRSS2. Potencjalnym mechanizmem podatności na SARS-CoV-2 zależnym od palenia może być zwiększona aktywność 
smoking-dependent mechanism of susceptibility to SARS-CoV-2 (24).

Farsalinos et al. identified an amino acid sequence (375-390) in the SARS-CoV-2 spike glycoprotein receptor binding domain homologous to the snake venom neurotoxin NL1 sequence, which is known to interact with nicotinic acetylcholine receptors (nAChR). The interaction pattern between amino acids 381-386 of SARS-CoV-2 S glycoprotein and amino acids 189-192 of the extracellular domain of the $\alpha 9 \mathrm{nAChR}$ subunit, the region that forms the toxin binding site with the $\mathrm{nAChR}$, is very similar to the interaction between the $\alpha 9 \mathrm{nAChR}$ and another neurotoxin, $\alpha$-bungarotoxin. A similar interaction was observed between the pentameric $\alpha 7$ AChR chimera and SARS-CoV-2 S glycoprotein. Nicotine and other nicotinic cholinergic agonists may have therapeutic value in COVID-19 patients because they protect the receptor from the viral $\mathrm{S}$ protein by competitively binding to $\mathrm{nAChR}$ (19). szlaku sygnalizacji androgenów w połączeniu ze zwiększoną ekspresją ACE2 (24).

Farsalinos i wsp. zidentyfikowali sekwencję aminokwasów (375-390) w domenie wiążącej receptory glikoproteiny kolca SARS-CoV-2 homologiczną z sekwencją neurotoksyny NL1 z jadu węży, o której wiadomo, że oddziałuje z nikotynowymi receptorami acetylocholiny (nAChR). Sposób interakcji między aminokwasami 381-386 glikoproteiny S SARS-CoV-2 a aminokwasami 189-192 domeny zewnątrzkomórkowej podjednostki nAChR $\alpha 9$, regionu, który tworzy miejsce wiązania toksyny z nAChR, jest bardzo podobny do interakcji między $\alpha 9$ nAChR i inną neurotoksyną - $\alpha$-bungarotoksyną. Między pentameryczną chimerą $\alpha 7 \mathrm{AChR}$ a glikoproteiną S SARS-CoV-2 obserwowano podobną interakcję. Nikotyna i inni nikotynowi agoniści cholinergiczni mogą mieć wartość terapeutyczną u pacjentów z COVID-19, ponieważ chronią receptor przed białkiem $\mathrm{S}$ wirusa poprzez kompetycyjne związanie się z nAChR (19).

Table I. Characteristics of selected studies included in the analysis of the mechanisms of nicotine influence on the human body in the context of SARS-CoV-2 infection (4,19,22-24)

Tabela I. Charakterystyka wybranych badań włączonych do analizy dotyczących mechanizmów wpływu nikotyny na organizm człowieka w kontekście zakażenia SARS-CoV-2 (4,19,22-24)

\begin{tabular}{|c|c|c|c|c|}
\hline $\begin{array}{c}\text { Authors / } \\
\text { Autorzy }\end{array}$ & $\begin{array}{c}\text { Type } \\
\text { of study / } \\
\text { Rodzaj } \\
\text { badania }\end{array}$ & $\begin{array}{c}\text { Country / } \\
\text { Miejsce } \\
\text { wykonania } \\
\text { badania }\end{array}$ & $\begin{array}{l}\text { Results / } \\
\text { Wyniki }\end{array}$ & $\begin{array}{c}\text { Conclusions / } \\
\text { Wnioski }\end{array}$ \\
\hline $\begin{array}{l}\text { Smith J.C. } \\
\text { et al. }\end{array}$ & $\begin{array}{l}\text { observational } \\
\text { study / } \\
\text { badanie } \\
\text { obserwacyjne }\end{array}$ & USA & $\begin{array}{l}\text { - cigarette smoke causes a dose- } \\
\text { dependent upregulation of ACE2 } \\
\text { expression, which is the SARS- } \\
\text { CoV-2 receptor / } \\
\text { - dym papierosowy powoduje } \\
\text { zależną od dawki regulację } \\
\text { w górę ekspresji ACE2, który jest } \\
\text { receptorem SARS-CoV-2 }\end{array}$ & $\begin{array}{l}\text { - the increased incidence of } \\
\text { COVID-19 in men and older } \\
\text { patients is unlikely to be due to } \\
\text { differences in the baseline level of } \\
\text { ACE2 expression in the lungs / } \\
\text { - jest mało prawdopodobne, aby } \\
\text { zwiększona zachorowalność } \\
\text { mężczyzn i starszych pacjentów } \\
\text { na COVID-19 wynikała z różnic } \\
\text { w podstawowym poziomie ekspresji } \\
\text { ACE2 w płucach }\end{array}$ \\
\hline $\begin{array}{c}\text { Voinsky I. } \\
\text { et al. }\end{array}$ & $\begin{array}{l}\text { observational } \\
\text { study / } \\
\text { badanie } \\
\text { obserwacyjne }\end{array}$ & Israel & $\begin{array}{l}\text { - increased expression of TMPRSS4 } \\
\text { in bronchial epithelial cells in } \\
\text { current smokers compared to those } \\
\text { who have never smoked, this may } \\
\text { be due to chronic exposure to } \\
\text { nicotine, acetaldehyde and tar and } \\
\text { results in bronchial inflammation/ } \\
\text { - podwyższony poziom ekspresji } \\
\text { TMPRSS4 w komórkach nabłonka } \\
\text { oskrzeli u obecnych palaczy } \\
\text { w porównaniu z osobami, które } \\
\text { nigdy nie paliły, może to wynikać } \\
\text { z przewlekłego narażenia na } \\
\text { nikotynę, aldehyd octowy } \\
\text { i substancje smoliste i skutkuje } \\
\text { stanem zapalnym oskrzeli }\end{array}$ & $\begin{array}{l}\text { - increased levels of TMPRSS4 in } \\
\text { the bronchi of smokers may put } \\
\text { them at greater risk of SARS-CoV-2 } \\
\text { infection/ } \\
\text { - podwyższone poziomy TMPRSS4 } \\
\text { w oskrzelach u palaczy mogą } \\
\text { narazić ich na większe ryzyko } \\
\text { zakażenia SARS-CoV-2 }\end{array}$ \\
\hline
\end{tabular}




\begin{tabular}{|c|c|c|c|c|}
\hline $\begin{array}{c}\text { Chakladar } \\
J . \text { et al. }\end{array}$ & $\begin{array}{l}\text { observational } \\
\text { study / } \\
\text { badanie } \\
\text { obserwacyjne }\end{array}$ & USA & $\begin{array}{l}\text { - increased levels of ACE } 2 \text { and } \\
\text { TMPRSS2 proteins in samples from } \\
\text { the epithelial tissue of the lungs and } \\
\text { mouth of smokers } \\
\text { - the androgen receptor increases } \\
\text { the expression of TMPRSS2 / } \\
\text { - podwyższone poziomy białek } \\
\text { ACE2 i TMPRSS } 2 \text { w próbkach } \\
\text { z tkanki nabłonkowej płuc i jamy } \\
\text { ustnej palaczy, } \\
\text { - receptor androgenowy zwiększa } \\
\text { ekspresję TMPRSS2 }\end{array}$ & $\begin{array}{l}\text { - increased activity of the androgen } \\
\text { signaling pathway in combination } \\
\text { with increased ACE2 expression } \\
\text { may be a potential mechanism of } \\
\text { smoking-dependent susceptibility to } \\
\text { SARS-CoV-2 / } \\
\text { - potencjalnym mechanizmem } \\
\text { podatności na SARS-CoV-2 } \\
\text { zależnej od palenia może być } \\
\text { zwiększona aktywność szlaku } \\
\text { sygnalizacji androgenów } \\
\text { w połączeniu ze zwiększoną } \\
\text { ekspresją ACE2 }\end{array}$ \\
\hline $\begin{array}{c}\text { Farsalinos } \\
K . \text { et al. }\end{array}$ & $\begin{array}{l}\text { in silico study / } \\
\text { badanie in } \\
\text { silico }\end{array}$ & Greece & $\begin{array}{l}\text { - the results of amino acid } \\
\text { sequence analyzes of the viral } \\
\text { S glycoprotein and } \alpha 9 \text { nAChR } \\
\text { indicate the possibility of SARS- } \\
\mathrm{CoV}-2 \text { interaction with nAChR, } \\
\text { which confirms the hypothesis } \\
\text { of dysregulation of the nicotinic } \\
\text { cholinergic system in the course of } \\
\text { COVID-19 / } \\
\text { - wyniki analiz sekwencji } \\
\text { aminokwasów glikoproteiny S } \\
\text { wirusa i } \alpha 9 \text { nAChR wskazują na } \\
\text { możliwość interakcji SARS-CoV-2 } \\
\text { z nAChR, co potwierdza hipotezę } \\
\text { o rozregulowaniu nikotynowego } \\
\text { układu cholinergicznego } \\
\text { w przebiegu COVID-19 }\end{array}$ & $\begin{array}{l}\text { - nicotine and other nicotinic } \\
\text { cholinergic agonists protect the } \\
\text { nAChR receptor from the viral } \\
\text { S protein, which can be used as } \\
\text { a therapeutic target / } \\
\text {-nikotyna i inni nikotynowi } \\
\text { agoniści cholinergiczni chronią } \\
\text { receptor nAChR przed białkiem S } \\
\text { wirusa, co może być wykorzystane } \\
\text { jako cel terapeutyczny }\end{array}$ \\
\hline $\begin{array}{l}\text { Simons } D . \\
\quad \text { et al. }\end{array}$ & $\begin{array}{c}\text { meta-analysis } \\
\text { of } 32 \text { studies / } \\
\text { metaanaliza } \\
32 \text { badań }\end{array}$ & $\begin{array}{l}\text { United } \\
\text { Kingdom }\end{array}$ & $\begin{array}{l}\text { - cigarette smoke reduces the } \\
\text { immunity of the respiratory } \\
\text { system by causing inflammation } \\
\text { and peribronchial fibrosis, } \\
\text { impaired mucociliary clearance } \\
\text { and disruption of the respiratory } \\
\text { epithelium, which promotes more } \\
\text { frequent infections / } \\
\text { - dym papierosowy obniża } \\
\text { odporność układu oddechowego } \\
\text { przez wywoływanie zapalenia } \\
\text { i zwłóknienia okołooskrzelowego, } \\
\text { upośledzenie klirensu śluzowo- } \\
\text { rzęskowego oraz przerwanie } \\
\text { ciągłości nabłonka oddechowego, co } \\
\text { sprzyja częstszym infekcjom }\end{array}$ & $\begin{array}{l}\text { - current smokers appear to have } \\
\text { a lower risk of SARS-CoV-2 } \\
\text { infection compared to those who } \\
\text { have never smoked, while ex- } \\
\text { smokers appear to be at higher risk } \\
\text { of hospitalization, increased disease } \\
\text { severity and COVID-19 mortality / } \\
\text { - obecni palacze wydają się } \\
\text { mieć mniejsze ryzyko zakażenia } \\
\text { SARS-CoV-2 w stosunku do osób } \\
\text { które nigdy nie paliły, podczas } \\
\text { gdy byli palacze wydają się być } \\
\text { bardziej narażeni na hospitalizację, } \\
\text { zwiększoną ciężkość choroby } \\
\text { i śmiertelność z powodu COVID-19 }\end{array}$ \\
\hline
\end{tabular}

The limitation of this type of literature review is the lack of a large number of high-quality original studies verifying the hypothesis of the influence of nicotine on the disease and course of COVID-19. Its strength is the inclusion of several meta-analyses, which are the most reliable source of scientific knowledge according to the evidence-based medicine pyramid. Data from the analyzed literature are collected in the table (Table I).
Ograniczeniem tego typu przeglądu piśmiennictwa jest brak dużej ilości wysokiej jakości badań oryginalnych weryfikujących hipotezę wpływu nikotyny na zachorowanie i przebieg COVID-19. Mocną stroną jest uwzględnienie kilku metaanaliz, będących najbardziej wiarygodnym źródłem wiedzy naukowej według piramidy evidence-based medicine. $\mathrm{W}$ tabeli zebrano dane $\mathrm{z}$ analizowanej literatury (Tab. I). 


\section{The impact of smoking traditional cigarettes on the incidence of COVID-19}

Smoking-related medical conditions such as lung cancer, COPD, and asthma are considered as risk factors for infection with SARS-CoV-2 virus (5). Therefore, a high prevalence of smoking is suspected among people with COVID-19.

Tsigaris and Teixiera da Silva carried out a study that investigated the connection between smoking prevalence and the incidence and mortality of COVID-19 in 38 European countries. It was observed that countries with more smokers had fewer COVID-19 cases per million people. A nation with more than $10 \%$ of smokers in a million people experienced a $15 \%$ lower incidence of COVID-19. A statistically significant negative correlation was found between smoking level in the adult population and the prevalence of COVID-19 after verifying potential confounding factors such as economic activity, COVID-19 testing rate, and the strength of pandemic containment policies (8).

A cross-sectional study from the United Kingdom investigated the association between handwashing, smoking, e-cigarette use and nicotine replacement therapy (NRT) use and subjective reporting of COVID-19 symptoms. 3,179 people aged over 18 were included in the study. Tattan-Birch et al. showed that current smokers and long-term smokers reported symptoms of coronavirus much more often compared to non-smokers (13). However, no difference was found between smoking status (smoker, short-term ex-smoker ( $<1$ year), long-term ex-smoker ( $>1$ year), and never smoker), use of traditional cigarettes, e-cigarettes, NRT, and socioeconomic status (13). Another crosssectional study carried out in the same country showed similar results. Jackson et al. investigated the effects of smoking on SARS-CoV-2 infection by considering potential confounding variables. Ultimately 53,002 participants were enrolled in the study. The authors showed that current smokers are 1.8 times more likely to be infected with the SARS-CoV-2 virus than nonsmokers, regardless of age, gender, ethnicity, work, or comorbidities (14).

\section{The impact of smoking traditional cigarettes on the course of SARS-CoV-2 virus infection}

It was estimated that smokers were 1.4 times more likely to experience severe COVID-19 symptoms and about 2.4 times more likely to it than non-smokers who were placed in the intensive care unit, required mechanical ventilation, or died (25). However, some studies have noted that the number of current smokers hospitalized for SARS-CoV-2 infection is lower than expected, taking into account the prevalence of smoking. A comparison of five different studies from China showed a total of 159 smokers among
Wpływ palenia papierosów tradycyjnych na zachorowalność na COVID-19

Stany chorobowe związane z paleniem, jak rak płuca, POChP czy astma są postrzegane jako czynniki ryzyka zakażenia wirusem SARS-CoV-2 (5). W związku z tym podejrzewa się wysoką częstość występowania palaczy pośród osób chorych na COVID-19.

Tsigaris i Teixiera da Silva wykonali badanie, w którym zamierzali sprawdzić powiązanie między rozpowszechnieniem palenia a zapadalnością i śmiertelnością z powodu COVID-19 w 38 europejskich krajach. Zaobserwowano, że kraje o większej liczbie palaczy cechowały się obecnością mniejszej liczby przypadków COVID-19 na milion osób. Naród mający więcej niż $10 \%$ palaczy na milion ludzi doświadczał o $15 \%$ niższej częstości występowania COVID-19. Stwierdzono statystycznie istotną ujemną korelację między poziomem palenia w populacji dorosłych i częstością występowania COVID-19 po sprawdzeniu potencjalnych czynników zakłócających, takich jak działalność gospodarcza, wskaźnik przeprowadzania testów na COVID-19 i siłę polityki powstrzymywania pandemii (8).

W badaniu przekrojowym wykonanym w Wielkiej Brytanii zbadano związek między myciem rąk, paleniem, stosowaniem e-papierosów oraz nikotynowej terapii zastępczej (NRT) a subiektywnym zgłaszaniem objawów COVID-19. Do badania włączono 3179 osób w wieku powyżej 18 roku życia. Tattan-Birch i wsp. wykazali, że obecni palacze oraz palacze długoterminowi zgłaszali zdecydowanie częściej objawy koronawirusa w porównaniu z osobami niepalącymi (13). Nie wykryto jednak różnicy pomiędzy statusem palenia (palacz, krótkoterminowy były palacz $(<1$ roku), długoterminowy były palacz ( $>1$ roku) i osoba nigdy nie paląca), stosowaniem tradycyjnych papierosów, e-papierosów, NRT a statusem socjoekonomicznym (13). Inne badanie przekrojowe wykonane $\mathrm{w}$ tym samym kraju ukazało podobne wyniki. Jackson ze współpracownikami badali wpływ palenia na zakażenie wirusem SARS-CoV-2, uwzględniając potencjalne zmienne zakłócające. Do badania ostatecznie włączono 53002 osoby. Autorzy wykazali, że u osób obecnie palących prawdopodobieństwo występowania potwierdzonego zakażenia wirusem SARS-CoV-2 jest 1,8 razy większe, w stosunku do osób niepalących niezależnie od wieku, płci, pochodzenia etnicznego, wykonywanej pracy czy chorób współtowarzyszących (14).

\section{Wpływ palenia papierosów tradycyjnych na prze- bieg infekcji wirusem SARS-CoV-2}

Szacuje się na podstawie analiz, że palacze byli 1,4 razy bardziej narażeni na ciężkie objawy COVID-19 i około 2,4 razy częściej niż osoby niepalące byli umieszczani na oddziale intensywnej terapii, wymagali wentylacji mechanicznej lub umierali (25). W części 
hospitalized COVID-19 patients, whereas, taking into account the smoking rate in China, the number of expected smoking patients with COVID-19 was estimated at 526 (6). A case-control study conducted in Italy aimed to assess the prevalence of smoking among patients hospitalized in seven non-intensive care units for COVID-19. The study included 218 patients with confirmed SARS-CoV-2 infection and 243 controls. Meini and co-authors observed that the prevalence of current smokers was significantly lower among people hospitalized for COVID-19 than among control patients hospitalized for other reasons $(4.1 \%$ versus $16 \%$ ). Non-smokers made up $71.6 \%$ of patients hospitalized due to COVID-19 and 56.8\% hospitalized for other reasons. A strong and statistically significant negative relationship was found between current smoker status and COVID-19 hospitalization in terms of gender and age (7). Data from the Tsigaris and Teixier da Silva study did not indicate a relationship between smoking prevalence and the death rate from COVID-19 per million people (8).

Most meta-analyses are based on comparing the results of the same studies that were most often performed in China, taking into account different aspects related to smoking. The largest meta-analysis included in the study, aimed at determining the link between smoking and COVID-19, conducted by Reddy et al. It included 47 studies involving a total of 32,849 patients hospitalized for COVID-19, where 8,417 patients (25.6\%) reported a smoking incident in the past. In 27 studies it was found that current smokers have an increased risk of severe symptoms and are exposed to the serious or critical effects of COVID-19 twice as often as former smokers or non-smokers. However, no significant influence of current smoking on hospital outcomes (disease progression, admission to the intensive care unit, need for mechanical ventilation, or mortality) was found (15). Taking into account not only current smokers, but also ex-smokers, an analysis of 35 studies was carried out, which showed that patients with a history of smoking had a significantly greater risk of severe and critical symptoms of COVID-19 and hospital complications. The surprising finding is that a history of smoking increases the risk of in-hospital mortality, whereas it has not been reported among current smokers (15). Similar relationships between smoking and the severity of symptoms of SARS$\mathrm{CoV}-2$ infection were found in the meta-analysis by Gülsen et al. 16 retrospective studies were included in the study, and 10,797 people were finally enrolled. Among the severe or critical patients, the average smoking prevalence was $8.4 \%$. The prevalence of former smokers in the group of patients with severe and critical symptoms of COVID-19 was $12.5 \%$, while in the group of patients with mild to moderate badań zauważono jednak, że liczba obecnych palaczy hospitalizowanych z powodu infekcji wirusem SARSCoV-2 jest niższa niż oczekiwano, biorąc pod uwagę rozpowszechnienie palenia. Porównanie pięciu różnych badań z Chin wskazywało na łącznie 159 palaczy wśród hospitalizowanych z powodu COVID-19, przy czym, uwzględniając współczynnik palaczy w Chinach, liczbę oczekiwanych palących pacjentów z COVID-19 szacowano na 526 (6). Badanie kliniczno-kontrolne wykonane we Włoszech miało na celu ocenić rozpowszechnienie palenia wśród pacjentów hospitalizowanych na siedmiu oddziałach innych niż intensywnej terapii z powodu COVID-19. Do badania włączono 218 pacjentów z potwierdzonym zakażeniem wirusem SARS-CoV-2 i 243 osoby grupy kontrolnej. Meini ze współautorami zaobserwowali, iż rozpowszechnienie obecnych palaczy było zdecydowanie niższe wśród osób hospitalizowanych z powodu COVID-19 niż wśród pacjentów z próby kontrolnej hospitalizowanych z innych powodów (4,1\% vs $16 \%$ ). Osoby niepalące stanowiły natomiast $71,6 \%$ pacjentów hospitalizowanych z powodu COVID-19 i 56,8\% przebywających w szpitalu z innych powodów. Wykryto silny i istotny statystycznie negatywny związek pomiędzy statusem obecnego palacza a pobytem w szpitalu z powodu COVID-19 w odniesieniu do płci i wieku (7). Dane z badania Tsigaris i Teixiera da Silva nie wskazały na powiązanie między rozpowszechnieniem palenia a śmiertelnością z powodu COVID-19 na milion osób (8).

Większość metaanaliz opiera się na porównaniu wyników tych samych badań, które najczęściej były wykonywane w Chinach, biorąc pod uwagę różne aspekty związane z paleniem. Największa uwzględniona metaanaliza, mająca na celu określenie związku między paleniem a COVID-19, została przeprowadzona przez Reddy i wsp. Liczyła ona 47 badań, do których włączono w sumie 32849 pacjentów hospitalizowanych z powodu COVID-19, gdzie 8417 (25,6\%) zgłosiło incydent palenia w przeszłości. W 27 badaniach stwierdzono, że obecni palacze posiadają zwiększone ryzyko ciężkich objawów i są narażeni na poważne lub krytyczne skutki COVID-19 dwukrotnie częściej niż byli palacze czy osoby niepalące. Nie stwierdzono jednak istotnego wpływu obecnego palenia na wyniki szpitalne (progresję choroby, przyjęcie na oddział intensywnej terapii, potrzebę mechanicznej wentylacji czy śmiertelność) (15). Biorąc pod uwagę nie tylko obecnych palaczy, ale również byłych palaczy, dokonano analizy 35 badań, z której wynikało, iż pacjenci z historią palenia mieli znacznie większe ryzyko ciężkich oraz krytycznych objawów COVID-19 oraz powikłań szpitalnych. Zaskakującym odkryciem jest, że historia palenia w wywiadzie zwiększa ryzyko śmiertelności wewnątrzszpitalnej, gdzie wśród obecnych palaczy zjawiska tego nie odnotowano (15). Podobne zależno- 
symptoms it was $5.2 \%$. Data in the group of current smokers were similar - current smokers with mild to moderate COVID-19 accounted for $2.9 \%$ of patients, while with severe or critical cases it was $5.8 \%$ patients. Symptoms of severe COVID-19 (21.2\%) were more frequent among current smokers than non-smokers $(10.7 \%)$. There was a significant correlation between smoking and the severity of symptoms of the disease, both in current as well as former smokers (16). Another meta-analysis presenting the relationship between smoking and the severity of COVID-19 was performed by Patanavani et al. based on 19 studies. A total of 11,590 patients were included in the study, of which 2,133 (18.4\%) experienced disease progression and $731(6.3 \%)$ were smokers. Among 218 smokers, $29.8 \%$ experienced disease progression, while among non-smokers, it worsened among $17.6 \%$. The authors found that smoking is a risk factor for COVID-19 progression, while smokers have a 1.91 times greater risk of it than people who have never smoked (17).

Farsalinos and co-authors performed a metaanalysis of the results of 18 retrospective studies conducted in China $(\mathrm{n}=15)$, the United States $(\mathrm{n}=$ 2), and South Korea $(n=1)$, including a total of 6,515 patients hospitalized for COVID-19, 440 of which were current smokers. An unexpectedly low current smoking rate was detected among COVID-19 patients and it was approximately $1 / 4$ of the expected smoking prevalence based on a gender-adjusted smoking index (9). Current smokers were more likely to experience side effects than current non-smokers, while current smokers were less likely to experience adverse effects than ex-smokers (9). A meta-analysis published by González-Rubio et al. showed similar results. It includes 18 studies considering smoking and its incidence in hospitalized people infected with SARSCoV-2 in China, the USA and Italy. In this study, two meta-analyses were performed - one for studies from China only, and the other for studies from all countries. These studies indicate that the proportion of smokers hospitalized for COVID-19 is noticeably lower than expected, taking into account the number of smokers in these countries as well as the possibility of errors in the reports. The percentage of smokers infected with the SARS-CoV-2 virus in China was $7.7 \%$ (smoking prevalence in this country 26.1\%), in the United States $1.7 \%$ and $5.1 \%$ (for two studies, respectively), while in Italy $7.6 \%$ (10). Researchers found several factors that could translate into results, including the lack of detailed studies of age groups or the concealing smoking in the medical interview. The results of this meta-analysis suggest that smoking addiction reduces the likelihood of hospitalization due to COVID-19 (10).

Sanchez-Ramirez and Mackey included 22 studies in their meta-analysis, including 13 studies on the ści między paleniem a nasileniem objawów zakażenia SARS-CoV-2 wysnuto w metaanalizie Gülsen i wsp. Włączono do niej 16 badań retrospektywnych, do których ostatecznie zakwalifikowano 10797 osób. Pośród pacjentów w stanie ciężkim lub krytycznym średnia częstość palaczy wynosiła średnio 8,4\%. Powszechność palenia w przeszłości w grupie chorych z ciężkimi, jak i krytycznymi objawami COVID-19 wynosiła 12,5\%, natomiast $\mathrm{w}$ grupie pacjentów $\mathrm{z}$ łagodnymi do umiarkowanych objawów zakażenia SARS-CoV-2 liczba byłych palaczy wynosiła $5,2 \%$. Dane w grupie osób aktualnie palących były podobne - obecnie palący $z$ łagodnym do umiarkowanego COVID-19 stanowili 2,9\% pacjentów, zaś przy ciężkich lub krytycznych przypadkach było to $5,8 \%$ osób. Wśród pacjentów obecnie palących częściej występowały objawy ciężkiego COVID-19 (21,2\%) niż u osób niepalących (10,7\%). Stwierdzono znaczące powiązanie między paleniem a nasileniem objawów choroby, zarówno u aktualnych palaczy, jak i osób z historią palenia (16). Kolejna metaanaliza ukazująca zależność między paleniem a ciężkością przebiegu COVID-19 została wykonana przez Patanavanich i wsp. na podstawie 19 artykułów. Łącznie do badania włączono 11590 pacjentów z czego $2133(18,4 \%)$ doświadczyło progresji choroby, a 731 (6,3\%) było palaczami. Pośród 218 pacjentów palących, u 29,8\% doszło do progresji choroby, podczas gdy u osób niepalących pogorszenie nastąpiło wśród 17,6\%. Autorzy stwierdzili, że palenie jest czynnikiem ryzyka progresji COVID-19, przy czym palacze mają 1,91 razy większe jej ryzyko w stosunku do osób, które nigdy nie paliły (17).

Farsalinos wraz ze współautorami wykonali metaanalizę wyników 18 badań retrospektywnych przeprowadzonych w Chinach $(n=15)$, Stanach Zjednoczonych $(n=2)$ i Korei Południowej $(n=1)$, obejmującą łącznie 6 515 pacjentów hospitalizowanych z powodu COVID-19, z czego 440 było obecnymi palaczami. Wykryto nieoczekiwanie niską częstość aktualnego palenia wśród pacjentów z COVID-19 i stanowiła ona około 1/4 spodziewanego rozpowszechnienia palenia opartego na wskaźniku palenia dostosowanego do płci (9). Obecni palacze mieli większe szanse na działania niepożądane w porównaniu z osobami obecnie niepalącymi, z kolei u obecnych palaczy prawdopodobieństwo wystąpienia niekorzystnych następstw było mniejsze w porównaniu z byłymi palaczami (9). Metaanaliza opublikowana przez González-Rubio i wsp. ukazała podobne wyniki. Uwzględniono w niej 18 badań dotyczących zjawiska palenia oraz jego częstości występowania u hospitalizowanych osób zakażonych SARS-CoV-2 w Chinach, USA i Włoszech. W powyższej pracy wykonano dwie metaanalizy - jedną wyłącznie dla badań z Chin, drugą zaś dla badań ze wszystkich krajów. Badania te wskazują, że odsetek palaczy hospitalizowanych z powodu COVID-19 jest dostrzegalnie niższy niż zakładano, 
relationship between smoking (now or in the past) and the severity of confirmed COVID-19. There was a higher prevalence of smokers, both current and exsmokers, among patients with severe COVID-19 (13\% and $6 \%$, respectively). Patients with a milder course of SARS-CoV-2 infection were less frequently exposed to tobacco smoke - current smokers accounted for $6 \%$, and ex-smokers $-3 \%$ of patients (11). Alqahtani et al. analyzed 8 studies on smoking (221 people with confirmed infection) and found $9 \%$ of current smokers among COVID-19 patients, with an estimated 25.2\% of smoking prevalence in the general population. Additionally, they estimated that $22.3 \%$ of current and $46 \%$ of ex-smokers had serious complications, and found higher mortality rates among current smokers, reaching $38.5 \%$ (12). Both studies indicate an increased risk of severe infection with the novel coronavirus in current and former smokers. The summary is presented in the table below (Table II).

\section{Comparison of smoking electronic cigarettes and traditional cigarettes in the context of COVID-19 incidence}

Electronic cigarettes have grown in popularity in recent years, especially among younger people. This trend is worrying because these devices are not safer - they are still tobacco products that, like traditional cigarettes, can cause lung damage $(1,25)$.

In the United States, a survey of adolescents and young adults $(n=4,351)$ aged $13-24$ years $(n=4,351)$ aged 13-24 was conducted in May, which assessed that the incidence of COVID-19 was associated with the use of e-cigarettes alone and the concomitant use of e-cigarettes and traditional cigarettes. A diagnosis of biorąc pod uwagę liczbę osób palących w tych krajach, jak i możliwość występowania błędów w raportach. Odsetek palaczy zakażonych wirusem SARS-CoV-2 w Chinach wynosił 7,7\% (rozpowszechnienie palenia w tym kraju 26,1\%), w Stanach Zjednoczonych 1,7\% i 5,1\% (odpowiednio dla dwóch badań), natomiast we Włoszech 7,6\% (10). Badacze spostrzegli kilka czynników, które mogły przełożyć się na wyniki, między innymi brak szczegółowych badań grup wiekowych czy zatajanie palenia w wywiadzie. Wyniki tej metaanalizy sugerują, że nałóg palenia zmniejsza prawdopodobieństwo hospitalizacji z powodu COVID-19 (10).

Sanchez-Ramirez i Mackey do swojej metaanalizy włączyli 22 badania, w tym 13 badań na temat związku między paleniem tytoniu (obecnie lub w przeszłości) a ciężkością przebiegu potwierdzonego COVID-19. Zaobserwowano częstszą obecność palaczy, zarówno obecnych, jak i byłych, pośród pacjentów w ciężkim przebiegiem COVID-19 (odpowiednio 13\% i 6\%). U pacjentów z lżejszym przebiegiem zakażenia wirusem SARS-CoV-2 rzadziej stwierdzano narażenie na dym tytoniowy - obecni palacze stanowili $6 \%$, a byli palacze - 3\% pacjentów (11). Alqahtani i wsp. w swojej pracy opierającej się na 8 badaniach dotyczących palenia (221 osób z potwierdzonym zakażeniem), wykazali obecność $9 \%$ obecnych palaczy wśród pacjentów z COVID-19, przy czym w ogólnej populacji szacuje się częstość palenia na $25,2 \%$. Ponadto ocenili, że $22,3 \%$ obecnych i $46 \%$ byłych palaczy miało poważne powikłania, wykryli również większą śmiertelność u obecnych palaczy osiągającą 38,5\% (12). Oba badania wskazują na zwiększone ryzyko ciężkiego przebiegu zakażenia nowym koronawirusem u obecnych i byłych palaczy. Podsumowanie przedstawiono w poniższej tabeli (Tab. II).

Table II. Characteristics of selected studies included in the analysis of the influence of smoking traditional cigarettes on the incidence and the course of COVID-19 (7-12,15-17)

Tabela II. Charakterystyka wybranych badań włączonych do analizy dotyczących wpływu palenia papierosów tradycyjnych na zachorowalność i przebieg COVID-19 (7-12,15-17)

\begin{tabular}{|c|c|c|c|c|c|}
\hline $\begin{array}{l}\text { Authors / } \\
\text { Autorzy }\end{array}$ & $\begin{array}{l}\text { Type of } \\
\text { study / } \\
\text { Rodzaj } \\
\text { badania }\end{array}$ & $\begin{array}{l}\text { Country / } \\
\text { Miejsce } \\
\text { wykonania } \\
\text { badania }\end{array}$ & $\begin{array}{l}\text { Study group / } \\
\text { Grupa badana }\end{array}$ & $\begin{array}{l}\text { Results / } \\
\text { Wyniki }\end{array}$ & $\begin{array}{l}\text { Conclusions / } \\
\text { Wnioski }\end{array}$ \\
\hline $\begin{array}{l}\text { Tsigaris } P \text {. } \\
\quad \text { et al. }\end{array}$ & $\begin{array}{c}\text { observational } \\
\text { study / } \\
\text { badanie } \\
\text { obserwacyjne }\end{array}$ & Canada & $\begin{array}{c}\text { not applicable / } \\
\text { nie dotyczy }\end{array}$ & $\begin{array}{l}\text { - a nation with more than } 10 \% \text { of smokers } \\
\text { per million people experienced a } 15 \% \text { lower } \\
\text { incidence of COVID-19, a statistically } \\
\text { significant negative correlation between } \\
\text { smoking levels and the incidence of } \\
\text { COVID-19 } \\
\text { - no link was found between smoking } \\
\text { prevalence and COVID-19 mortality / } \\
\text { - naród mający więcej niż } 10 \% \text { palaczy na } \\
\text { milion ludzi doświadczał o } 15 \% \text { niższej } \\
\text { częstości występowania COVID-19, } \\
\text { statystycznie istotna ujemna korelacja między } \\
\text { poziomem palenia i częstością występowania } \\
\text { COVID-19,- nie wykryto powiązania między } \\
\text { rozpowszechnieniem palenia a śmiertelnością } \\
\text { z powodu COVID-19 }\end{array}$ & $\begin{array}{l}\text { - countries with more smokers } \\
\text { had fewer COVID-19 cases per } \\
\text { million people / } \\
\text { - kraje o większej liczbie } \\
\text { palaczy cechowały się } \\
\text { obecnością mniejszej liczby } \\
\text { przypadków COVID-19 na } \\
\text { milion osób }\end{array}$ \\
\hline
\end{tabular}




\begin{tabular}{|c|c|c|c|c|c|}
\hline $\begin{array}{l}\text { Meini } S \text {. } \\
\text { et al. }\end{array}$ & $\begin{array}{c}\text { observational } \\
\text { study (case- } \\
\text { control) / } \\
\text { badanie } \\
\text { obserwacyjne } \\
\text { (kliniczno- } \\
\text { kontrolne) }\end{array}$ & Italy & $\begin{array}{l}218 \text { patients } \\
\text { with confirmed } \\
\text { SARS-CoV-2 } \\
\text { virus infection and } \\
243 \text { people in the } \\
\text { control group / } \\
218 \text { pacjentów z } \\
\text { potwierdzonym } \\
\text { zakażeniem } \\
\text { wirusem SARS- } \\
\text { CoV-2 i } 243 \text { osoby } \\
\text { grupy kontrolnej }\end{array}$ & $\begin{array}{l}\text { - prevalence of current smokers was } \\
\text { significantly lower among people hospitalized } \\
\text { due to COVID-19 than among control patients } \\
\text { hospitalized for other reasons (4.1\% versus } \\
16 \% \text { ) } \\
\text { - non-smokers accounted for } 71.6 \% \text { of } \\
\text { patients hospitalized due to COVID-19 and } \\
56.8 \% \text { hospitalized for other reasons / } \\
\text { - rozpowszechnienie obecnych palaczy } \\
\text { było zdecydowanie niższe wśród osób } \\
\text { hospitalizowanych z powodu COVID-19 } \\
\text { niż wśród pacjentów z próby kontrolnej } \\
\text { hospitalizowanych z innych powodów }(4,1 \% \\
\text { vs } 16 \%),- \text { osoby niepalące stanowily } 71,6 \% \\
\text { pacjentów hospitalizowanych z powodu } \\
\text { COVID-19 i } 56,8 \% \text { przebywających w } \\
\text { szpitalu z innych powodów }\end{array}$ & $\begin{array}{l}\text { - unexpectedly low prevalence } \\
\text { of current smokers among } \\
\text { COVID-19 patients hospitalized } \\
\text { in non-ICU units } \\
\text { - strong and statistically } \\
\text { significant negative relationship } \\
\text { between current smoker status } \\
\text { and COVID-19 hospital stay in } \\
\text { terms of gender and age / } \\
\text { - nieoczekiwanie niska } \\
\text { częstość obecnych palaczy } \\
\text { wśród pacjentów z COVID-19 } \\
\text { hospitalizowanych na } \\
\text { oddziałach innych niż OIT- } \\
\text { silny i istotny statystycznie, } \\
\text { negatywny związek pomiędzy } \\
\text { statusem obecnego palacza a } \\
\text { pobytem w szpitalu z powodu } \\
\text { COVID-19 w odniesieniu do } \\
\text { płci i wieku }\end{array}$ \\
\hline $\begin{array}{l}\text { Reddy R.K. } \\
\quad \text { et al. }\end{array}$ & $\begin{array}{c}\text { meta-analysis } \\
\text { of } 47 \text { studies } \\
\text { (from China } \\
\text { and USA) / } \\
\text { metaanaliza } \\
47 \text { badań (z } \\
\text { Chin i USA) }\end{array}$ & $\begin{array}{c}\text { United } \\
\text { Kingdom }\end{array}$ & $\begin{array}{c}32,849 \text { patients } \\
\text { hospitalized } \\
\text { for COVID-19 } \\
(25.6 \% \text { reported } \\
\text { a smoking incident } \\
\text { in the past) / } \\
32849 \text { pacjentów } \\
\text { hospitalizowanych } \\
\text { z powodu } \\
\text { COVID-19 } \\
\text { (25,6\% zgłosiło } \\
\text { incydent palenia w } \\
\text { przeszłości) }\end{array}$ & $\begin{array}{l}\text { - current smokers have an increased risk } \\
\text { of severe symptoms and are exposed to the } \\
\text { serious or critical effects of COVID-19 twice } \\
\text { as often as former smokers or non-smokers } \\
\text { - no significant influence of current smoking } \\
\text { on hospital outcomes (disease progression, } \\
\text { admission to the ICU, need for mechanical } \\
\text { ventilation or mortality) } \\
\text { - a history of smoking increases the risk of } \\
\text { in-hospital mortality, which has not been } \\
\text { reported among current smokers / } \\
\text { - obecni palacze posiadają zwiększone ryzyko } \\
\text { ciężkich objawów i są narażeni na poważne } \\
\text { lub krytyczne skutki COVID-19 dwukrotnie } \\
\text { częściej niż byli palacze czy osoby niepalące,- } \\
\text { brak istotnego wpływu obecnego palenia } \\
\text { na wyniki szpitalne (progresję choroby, } \\
\text { przyjęcie na OIOM, potrzebę mechanicznej } \\
\text { wentylacji czy śmiertelność)- historia palenia } \\
\text { w wywiadzie zwiększa ryzyko śmiertelności } \\
\text { wewnątrzszpitalnej, czego nie odnotowano } \\
\text { wśród obecnych palaczy }\end{array}$ & $\begin{array}{l}\text { - both current smoking and } \\
\text { smoking history significantly } \\
\text { increased the severity of } \\
\text { COVID-19 } \\
\text { - smoking history significantly } \\
\text { increased the risk of mortality } \\
\text { from COVID-19/ } \\
\text { - zarówno obecne palenie, jak } \\
\text { i historia palenia znacząco } \\
\text { zwiększały ciężkość COVID-19, } \\
\text { - historia palenia znacząco } \\
\text { zwiększała ryzyko śmiertelności } \\
\text { z powodu COVID-19 }\end{array}$ \\
\hline $\begin{array}{l}\text { Gülsen A. } \\
\text { et al. }\end{array}$ & $\begin{array}{l}\text { meta- } \\
\text { analysis of } 16 \\
\text { retrospective } \\
\text { studies from } \\
\text { China and the } \\
\text { USA / } \\
\text { metaanaliza } \\
16 \text { badan } \\
\text { retrospek- } \\
\text { tywnych z } \\
\text { Chin i USA }\end{array}$ & Germany & $\begin{array}{c}\text { 10,797 COVID-19 } \\
\text { patients / } \\
10797 \text { pacjentów z } \\
\text { COVID-19 }\end{array}$ & $\begin{array}{l}\text { - in the group with severe and critical } \\
\text { symptoms of COVID-19, the number of } \\
\text { ex-smokers was } 12.5 \% \text {, while among patients } \\
\text { with mild to moderate symptoms - 5.2\% } \\
\text { - current smokers with mild to moderate } \\
\text { COVID-19 accounted for } 2.9 \% \text { of patients, } \\
\text { and } 5.8 \% \text { of patients with severe or critical } \\
\text { course } \\
\text { - among current smokers, symptoms of severe } \\
\text { COVID-19 were more frequent (21.2\%) than } \\
\text { non-smokers (10.7\%) / } \\
\text { - w grupie z ciężkimi i krytycznymi } \\
\text { objawami COVID-19 odsetek byłych palaczy } \\
\text { wynosił } 12,5 \%, \text { natomiast wśród pacjentów } \\
\text { z łagodnymi do umiarkowanych objawów } \\
\text { - 5,2\%,- obecnie palący z łagodnym do } \\
\text { umiarkowanego COVID-19 stanowili } 2,9 \% \\
\text { pacjentów, zaś z ciężkim lub krytycznym } \\
\text { przebiegiem 5,8\% osób,- wśród pacjentów } \\
\text { obecnie palących częściej występowały } \\
\text { objawy ciężkiego COVID-19 (21,2\%) niż u } \\
\text { osób niepalących (10,7\%) }\end{array}$ & $\begin{array}{l}\text { - there was a significant } \\
\text { association between smoking } \\
\text { and the severity of symptoms } \\
\text { of the disease, both in current } \\
\text { smokers and people with } \\
\text { a history of smoking / } \\
\text { - stwierdzono znaczące } \\
\text { powiązanie między paleniem a } \\
\text { nasileniem objawów choroby, } \\
\text { zarówno u aktualnych palaczy, } \\
\text { jak i osób z historią palenia }\end{array}$ \\
\hline
\end{tabular}




\begin{tabular}{|c|c|c|c|c|c|}
\hline $\begin{array}{c}\text { Patanavanich } \\
R . \text { et al. }\end{array}$ & $\begin{array}{c}\text { meta-analysis } \\
\text { of } 19 \text { studies } \\
\text { from China, } \\
\text { Korea and the } \\
\text { USA / } \\
\text { metaanaliza } \\
19 \text { badań z } \\
\text { Chin, Korei i } \\
\text { USA }\end{array}$ & USA & $\begin{array}{c}\text { 11,590 patients } \\
(6.3 \% \text { were } \\
\text { smokers }) / \\
11590 \text { pacjentów } \\
\text { (6,3\% stanowili } \\
\text { palacze) }\end{array}$ & $\begin{array}{l}\text { - out of } 218 \text { smoking patients, } 29.8 \% \\
\text { had progression, while non-smokers had } \\
\text { deterioration among } 17.6 \% \text { / } \\
\text { - pośród } 218 \text { pacjentów palących, u } 29,8 \% \\
\text { doszło do progresji choroby, podczas gdy } \\
\text { u osób niepalących pogorszenie nastąpiło } \\
\text { wśród } 17,6 \%\end{array}$ & $\begin{array}{l}\text { - smoking is a risk factor for } \\
\text { the progression of COVID-19, } \\
\text { smokers have a } 1.91 \text { times } \\
\text { higher risk than people who } \\
\text { have never smoked / } \\
\text { - palenie jest czynnikiem ryzyka } \\
\text { progresji COVID-19, palacze } \\
\text { mają } 1,91 \text { razy większe jej } \\
\text { ryzyko w stosunku do osób, } \\
\text { które nigdy nie paliły }\end{array}$ \\
\hline $\begin{array}{l}\text { Farsalinos } \\
\text { K. et al. }\end{array}$ & $\begin{array}{c}\text { meta- } \\
\text { analysis of } 18 \\
\text { retrospective } \\
\text { studies } \\
\text { (China, USA } \\
\text { and South } \\
\text { Korea)/ } \\
\text { metaanaliza } \\
18 \text { badań } \\
\text { retrospek- } \\
\text { tywnych } \\
\text { (Chiny, } \\
\text { USA i Korea } \\
\text { Południowa) }\end{array}$ & Greece & $\begin{array}{c}6,515 \text { patients } \\
\text { hospitalized } \\
\text { for COVID-19, } \\
440 \text { are current } \\
\text { smokers / } \\
6515 \text { pacjentów } \\
\text { hospitalizowanych } \\
\text { z powodu } \\
\text { COVID-19, z } \\
\text { czego } 440 \text { to } \\
\text { obecni palacze }\end{array}$ & $\begin{array}{l}\text { - the unexpectedly low incidence of current } \\
\text { smoking among COVID-19 patients at } 6.8 \% \text {, } \\
\text { was about } 1 / 4 \text { of the expected smoking } \\
\text { prevalence based on the gender-adjusted } \\
\text { smoking index } \\
\text { - current smokers were more likely to suffer } \\
\text { adverse effects compared to current non- } \\
\text { smokers, but less compared to ex-smokers / } \\
\text { - nieoczekiwanie niska częstość aktualnego } \\
\text { palenia wśród pacjentów z COVID-19 } \\
\text { na poziomie } 6,8 \% \text {, stanowiła około } 1 / 4 \\
\text { spodziewanego rozpowszechnienia } \\
\text { palenia opartego na wskaźniku palenia } \\
\text { dostosowanego do płci,- obecni palacze byli } \\
\text { bardziej narażeni na niekorzystne następstwa } \\
\text { w porównaniu z osobami obecnie nie } \\
\text { palącymi, ale mniej w porównaniu z byłymi } \\
\text { palaczami }\end{array}$ & $\begin{array}{l}\text { - current smokers are more } \\
\text { likely to experience side effects } \\
\text { than current non-smokers, but } \\
\text { lower than ex-smokers } \\
\text { - smoking cannot be considered } \\
\text { a protective measure against } \\
\text { COVID-19, due to the associated } \\
\text { risk of morbidity and mortality } \\
\text { from cardiovascular and } \\
\text { respiratory diseases and cancer / } \\
\text { - większe szanse na wystąpienie } \\
\text { działań niepożądanych u } \\
\text { obecnych palaczy w porównaniu } \\
\text { z osobami obecnie niepalącymi, } \\
\text { mniejsze jednak w porównaniu } \\
\text { z byłymi palaczami,- palenia } \\
\text { nie można uznać za środek } \\
\text { ochronny przeciw COVID-19, } \\
\text { ze względu na związane z } \\
\text { nim ryzyko zachorowalności i } \\
\text { śmiertelności na choroby układu } \\
\text { krążenia, układu oddechowego } \\
\text { oraz nowotwory }\end{array}$ \\
\hline $\begin{array}{l}\text { González- } \\
\text { Rubio J. } \\
\quad \text { et al. }\end{array}$ & $\begin{array}{l}\text { meta-analysis } \\
\text { of } 18 \text { studies } \\
\text { from China, } \\
\text { USA and } \\
\text { Italy / } \\
\text { metaanaliza } \\
18 \text { badań z } \\
\text { Chin, USA i } \\
\text { Włoch }\end{array}$ & Spain & $\begin{array}{c}\text { 7,671 COVID-19 } \\
\text { patients / } \\
7671 \text { pacjentów z } \\
\text { COVID-19 }\end{array}$ & $\begin{array}{l}\text { - the proportion of smokers infected with } \\
\text { the SARS-CoV-2 virus in China was } 7.7 \% \\
\text { (smoking prevalence in this country } 26.1 \% \text { ), } \\
\text { in the United States } 1.7 \% \text { and } 5.1 \% \text { (for two } \\
\text { studies, respectively), while in Italy } 7.6 \% \text { / } \\
\text { - odsetek palaczy zakażonych wirusem } \\
\text { SARS-CoV-2 w Chinach wynosił 7,7\% } \\
\text { (rozpowszechnienie palenia w tym kraju } \\
26,1 \% \text { ), w Stanach Zjednoczonych } 1,7 \% \\
\text { i 5,1\% (odpowiednio dla dwóch badań), } \\
\text { natomiast we Włoszech 7,6\% }\end{array}$ & $\begin{array}{l}\text { - the proportion of smokers } \\
\text { hospitalized for COVID-19 is } \\
\text { noticeably lower than expected, } \\
\text { taking into account the number } \\
\text { of smokers in these countries as } \\
\text { well as the possibility of errors } \\
\text { in reports } \\
\text { - the habit of smoking reduces } \\
\text { the likelihood of hospitalization } \\
\text { due to COVID-19/ } \\
\text { - odsetek palaczy } \\
\text { hospitalizowanych z powodu } \\
\text { COVID-19 jest dostrzegalnie } \\
\text { niższy niż zakładano, biorąc } \\
\text { pod uwagę liczbę osób palących } \\
\text { w tych krajach, jak i możliwość } \\
\text { występowania błędów w } \\
\text { raportach,- nałóg palenia } \\
\text { zmniejsza prawdopodobieństwo } \\
\text { hospitalizacji z powodu } \\
\text { COVID-19 }\end{array}$ \\
\hline $\begin{array}{l}\text { Sanchez- } \\
\text { Ramirez } \\
\text { D.C. et al. }\end{array}$ & $\begin{array}{l}\text { meta-analysis } \\
\text { of } 22 \text { studies } \\
\text { from China } \\
\text { and the USA / } \\
\text { metaanaliza } \\
22 \text { badań z } \\
\text { Chin i USA }\end{array}$ & Canada & $\begin{array}{l}\text { 9,440 COVID-19 } \\
\text { patients / } \\
\text { 9440 pacjentów z } \\
\text { COVID-19 }\end{array}$ & $\begin{array}{l}\text { - more frequent presence of both current } \\
\text { and ex-smokers in the group of patients with } \\
\text { a severe course of COVID-19 (13\% and 6\%, } \\
\text { respectively) } \\
\text { - in patients with a milder course of } \\
\text { COVID-19, exposure to tobacco smoke was } \\
\text { reported less frequently (current smokers } \\
\text { accounted for 6\%, and ex-smokers - 3\% of } \\
\text { patients) / } \\
\text { - częstsza obecność zarówno obecnych, jak i } \\
\text { byłych palaczy w grupie pacjentów z ciężkim } \\
\text { przebiegiem COVID-19 (odpowiednio } 13 \% \\
\text { i } 6 \% \text { ), u pacjentów z lżejszym przebiegiem } \\
\text { COVID-19 rzadziej stwierdzano narażenie na } \\
\text { dym tytoniowy (obecni palacze stanowili } 6 \% \text {, } \\
\text { a byli palacze - 3\% pacjentów) }\end{array}$ & $\begin{array}{l}\text { - increased risk of severe } \\
\text { infection with the new } \\
\text { coronavirus in current and } \\
\text { former smokers / } \\
\text { - zwiększone ryzyko ciężkiego } \\
\text { przebiegu zakażenia nowym } \\
\text { koronawirusem u obecnych i } \\
\text { byłych palaczy }\end{array}$ \\
\hline
\end{tabular}




\begin{tabular}{|c|c|c|c|c|c|}
\hline $\begin{array}{l}\text { Alqahtani } \\
\text { J.S. et al. }\end{array}$ & $\begin{array}{c}\text { meta-analysis } \\
\text { of } 8 \text { studies / } \\
\text { metaanaliza } 8 \\
\text { badań }\end{array}$ & $\begin{array}{c}\text { United } \\
\text { Kingdom }\end{array}$ & $\begin{array}{c}221 \text { people } \\
\text { with confirmed } \\
\text { COVID-19/ } \\
221 \text { osób z } \\
\text { potwierdzonym } \\
\text { COVID-19 }\end{array}$ & $\begin{array}{l}\text { - current smokers accounted for } 9 \% \text { of } \\
\text { COVID-19 patients (smoking incidence in the } \\
\text { general population - } 25.2 \% \text { ) } \\
-22.3 \% \text { of current and } 46 \% \text { of ex-smokers } \\
\text { had serious complications in the course of } \\
\text { COVID-19 } \\
\text { - higher mortality in current smokers } \\
\text { reaching } 38.5 \% \text { / } \\
\text { - obecni palacze stanowili } 9 \% \text { pacjentów } \\
\text { z COVID-19 (częstość palenia w ogólnej } \\
\text { populacji - } 25,2 \% \text { )- } 22,3 \% \text { obecnych i } 46 \% \\
\text { byłych palaczy miało poważne powikłania w } \\
\text { przebiegu COVID-19,- większa śmiertelność } \\
\text { u obecnych palaczy osiągająca } 38,5 \%\end{array}$ & $\begin{array}{l}\text { - increased risk of severe } \\
\text { infection with the novel } \\
\text { coronavirus in current and } \\
\text { former smokers / } \\
\text { - zwiększone ryzyko ciężkiego } \\
\text { przebiegu zakażenia nowym } \\
\text { koronawirusem u obecnych i } \\
\text { byłych palaczy }\end{array}$ \\
\hline
\end{tabular}

COVID-19 was five times more likely in the group of only e-cigarette users, seven times more likely among ever-smokers of both types of cigarettes, and 6.8 times more likely among those who smoked both in the last 30 days. The onset of symptoms was 4.7 times more likely in people who used both traditional and electronic cigarettes in the last 30 days (26).

\section{Comparison of smoking electronic cigarettes and traditional cigarettes in the context of the course of SARS-CoV-2 infection}

The World Health Organization emphasizes that smokers of traditional cigarettes, e-cigarettes, or waterpipe, may be more prone to an exacerbation of COVID-19 and serious health consequences (for example, conditions requiring mechanical ventilation) compared to non-smokers. There is evidence that e-cigarette fumes are less toxic than tobacco smoke from traditional cigarettes. Nevertheless, smoking e-cigarettes causes endothelial dysfunction, increases vascular and cerebral oxidative stress, and raises blood pressure. It is emphasized that smoking cessation is the most important way to prevent cardiovascular and respiratory diseases caused by smoking, which in themselves may increase the risk of a severe course of COVID-19 (2).

Increasing the activity of the ACE2 receptor may apply to new electronic smoking devices such as electronic cigarettes and IQOS devices of the "heatnot-burn" type (1). Lee et al. found that using tobacco and flavored or nicotine-containing e-cigarettes can lead to an increased inflammatory response, but only tobacco increases ACE2 activity. Smoking traditional and electronic cigarettes can critically exacerbate the inflammation associated with COVID-19 or increase susceptibility to the disease. Smoking is associated with increased immune cell infiltration, and elevated CD4 $\mathrm{T}$ cells in current tobacco smokers may lead to elevated levels of pro-inflammatory cytokines, making tobacco smokers more susceptible to an aggressive immune response. In users of e-cigarettes without nicotine and without flavor, no significant
Porównanie palenia papierosów elektronicznych i papierosów tradycyjnych w kontekście zachorowalności na COVID-19

Papierosy elektroniczne zyskały na popularności w ostatnich latach, szczególnie wśród osób w młodszym wieku. Tendencja ta jest niepokojąca, ponieważ urządzenia te nie są bezpieczniejsze - nadal są to wyroby zawierające tytoń, które, podobnie jak w przypadku tradycyjnych papierosów, mogą powodować uszkodzenie płuc $(1,25)$.

W Stanach Zjednoczonych przeprowadzono w maju badanie ankietowe wśród młodzieży i młodych dorosłych $(\mathrm{n}=4351) \mathrm{w}$ wieku 13-24 lat, w którym oceniono, że zachorowalność na COVID-19 wiąże się z używaniem przez młodzież wyłącznie e-papierosów oraz jednoczesnego używania e-papierosów i papierosów. Diagnoza COVID-19 była pięciokrotnie bardziej prawdopodobna w grupie osób kiedykolwiek używających tylko e-papierosów, siedem razy bardziej prawdopodobna wśród kiedykolwiek palących oba rodzaje papierosów i 6,8 razy bardziej prawdopodobna wśród palących oba rodzaje papierosów w ostatnich 30 dniach. Pojawienie się objawów było 4,7 razy bardziej prawdopodobne u osób stosujących papierosy tradycyjne i elektroniczne w ciągu ostatnich 30 dni (26).

Porównanie palenia papierosów elektronicznych i papierosów tradycyjnych w kontekście przebiegu infekcji SARS-CoV-2

Światowa Organizacja Zdrowia podkreśla, iż osoby palące papierosy tradycyjne, elektroniczne lub fajkę wodną mogą być bardziej podatne na zaostrzony przebieg COVID-19 i poważne konsekwencje zdrowotne (na przykład stany wymagające wentylacji mechanicznej) w porównaniu z osobami niepalącymi. Istnieją dowody na to, że opary e-papierosów są mniej toksyczne niż dym tytoniowy z papierosów tradycyjnych. Niemniej jednak, palenie e-papierosów powoduje dysfunkcję śródbłonka, zwiększa naczyniowy i mózgowy stres oksydacyjny oraz podwyższa ciśnienie tętnicze krwi. Podkreśla się, że zaprzestanie palenia jest najważniejszym sposobem zapobiegania chorobom układu krążenia i układu oddechowego wywołanym paleniem, które 
dysregulation of cytokines was found (only interferon alfa-8 was significantly increased) (27).

The detrimental effect of smoking traditional cigarettes and e-cigarettes on the integrity of the blood-brain barrier has been reported, which may cause the SARS-CoV-2 virus to accumulate in the central nervous system and lead to a more severe course of infection. At the same time, smoking increases the expression of the mediator of ACE2 viral invasion in endothelial cells, glial cells, and neurons. Also, elevated levels of von Willebrand factor in the bloodstream and lowered levels of thrombomodulin in smokers of both types of cigarettes can disrupt blood homeostasis promoting blood clotting and thrombus formation, severely increasing the risk of stroke and other cardiovascular events. The need for further research in this area was indicated (3).

Exposure to inhalation of nicotine and other irritants from electronic cigarettes has been shown to disrupt the homeostasis of the renin-angiotensin system. Inhibition of local compensatory mechanisms may lead to increased susceptibility to cardiovascular and respiratory disorders, hypothetically increasing the risk of severe COVID-19, similar to smoking traditional cigarettes. There was a significant increase in mucin 4, cell surface associated (MUC4) and an increase in the ratio of MUC5AC to MUC5B secretory mucins among e-cigarette users compared to nonsmokers (25) (Table III).

\section{The possibility of using nicotine to treat infection with SARS-CoV-2 virus}

Nicotine might be a new potential therapy for CRS (cytokine release syndrome) in patients with severe SARS-CoV-2. The use of nicotine pharmaceuticals such as nicotine patches, gums or inhalers as competing agonists for $\mathrm{nAChRs}$ may restore the impaired function of the nicotinic cholinergic system and possibly mitigate the cytokine storm more effectively than when using single cytokine inhibitors (6). Nicotine inhibits pro-inflammatory cytokines such as TNF, IL1, IL-6, and HMGB1, which, elevated among patients with COVID-19, induce a cytokine storm. It can cause acute respiratory distress syndrome (ARDS) and multisystem organ failure $(5,21,22)$. It was emphasized that smoking cannot be used to prevent infection with the SARS-CoV-2 virus. However, it seems extremely important to further investigate nicotine function in restoring the functioning of the cholinergic antiinflammatory system as well as in the fight against the COVID-19 pandemic (21).

Mohammadi et al. investigated the interaction between caffeine and nicotine and the human ACE2 receptor $\mathrm{S}$ protein of SARS-CoV-2 virus using molecular dynamics simulations. The simulation same w sobie mogą zwiększać ryzyko ciężkiego przebiegu COVID-19 (2).

Zwiększenie aktywności receptora ACE2 może dotyczyć nowych elektronicznych urządzeń do palenia, takich jak papierosy elektroniczne i urządzenia IQOS typu „heat-not-burn” (1). Lee i wsp. stwierdzili, że używanie tytoniu i aromatyzowanych lub zawierających nikotynę e-papierosów może prowadzić do zwiększonej odpowiedzi zapalnej, ale tylko tytoń zwiększa aktywność ACE2. Palenie papierosów tradycyjnych i elektronicznych może krytycznie zaostrzyć stan zapalny związany z COVID-19 lub zwiększyć podatność na zachorowanie. Palenie tytoniu wiąże się ze zwiększoną infiltracją komórek odpornościowych, a podwyższony poziom limfocytów T CD4 u obecnych palaczy tytoniu może prowadzić do podniesienia poziomu cytokin prozapalnych, czyniąc palaczy tytoniu bardziej podatnymi na agresywną odpowiedź immunologiczną. U użytkowników e-papierosów bez nikotyny i bez aromatu nie stwierdzono znaczącego rozregulowania cytokin (odnotowano znacząco podniesiony poziom tylko interferonu alfa-8) (27).

Wskazuje się na szkodliwy wpływ palenia papierosów tradycyjnych i e-papierosów na integralność bariery krew-mózg, co może powodować gromadzenie się w ośrodkowym układzie nerwowym wirusa SARSCoV-2 i prowadzić do cięższego przebiegu zakażenia. Jednocześnie palenie zwiększa ekspresję mediatora inwazji wirusa ACE2 w komórkach śródbłonka, gleju i neuronach. Ponadto, podwyższony poziom czynnika von Willebranda w krwiobiegu i obniżone poziomy trombomoduliny u palaczy obu rodzajów papierosów mogą zaburzać homeostazę krwi, sprzyjając krzepnięciu krwi i tworzeniu zakrzepu, co poważnie zwiększa ryzyko udaru i innych zdarzeń sercowo-naczyniowych. Wskazano na konieczność dalszych badań w tym zakresie (3).

Wykazano, że narażenie na wdychanie nikotyny i innych czynników drażniących pochodzących z papierosów elektronicznych zaburza homeostazę układu renina-angiotensyna. Hamowanie lokalnych mechanizmów kompensacyjnych może prowadzić do zwiększonej podatności na zaburzenia sercowo-naczyniowe i oddechowe, hipotetycznie zwiększając ryzyko ciężkiego przebiegu COVID-19, podobnie jak przy paleniu papierosów tradycyjnych. Wśród użytkowników papierosów elektronicznych, w porównaniu z osobami niepalącymi, odnotowano znaczący wzrost mucyny zakotwiczonej w błonie (MUC4) oraz wzrost stosunku mucyn wydzielniczych MUC5AC do MUC5B (25) (Tab. III).

\section{Możliwość wykorzystania nikotyny do leczenia in- fekcji wirusem SARS-CoV 2}

Nikotyna może stanowić nową potencjalną terapię CRS (cytokine release syndrom) u pacjentów z ciężkim 
Table III. Characteristics of selected studies included in the analysis comparing smoking of electronic cigarettes and traditional cigarettes in the context of the incidence and course of SARS-CoV-2 infection $(26,27)$

Tabela III. Charakterystyka wybranych badań włączonych do analizy porównujących palenie papierosów elektronicznych i papierosów tradycyjnych w kontekście zachorowalności i przebiegu infekcji SARS-CoV-2 $(26,27)$

\begin{tabular}{|c|c|c|c|c|c|}
\hline $\begin{array}{c}\text { Authors / } \\
\text { Autorzy }\end{array}$ & $\begin{array}{c}\text { Type of study / } \\
\text { Rodzaj } \\
\text { badania }\end{array}$ & $\begin{array}{l}\text { Country / } \\
\text { Miejsce } \\
\text { wykonania } \\
\text { badania }\end{array}$ & $\begin{array}{l}\text { Study group / } \\
\text { Grupa badana }\end{array}$ & $\begin{array}{l}\text { Results / } \\
\text { Wyniki }\end{array}$ & $\begin{array}{l}\text { Conclusions / } \\
\text { Wnioski }\end{array}$ \\
\hline $\begin{array}{c}\text { Gaiha } \\
\text { S.M. et al. }\end{array}$ & $\begin{array}{c}\text { survey study / } \\
\text { badanie } \\
\text { ankietowe }\end{array}$ & USA & $\begin{array}{c}\text { 4,351 people } \\
\text { aged 13-24 / } \\
4351 \text { osób w } \\
\text { wieku 13-24 lat }\end{array}$ & $\begin{array}{l}\text { - COVID-19 is } 5 \text { times more likely } \\
\text { in the group of people who ever use } \\
\text { only e-cigarettes, } 7 \text { times more likely } \\
\text { among ever smokers of e-cigarettes } \\
\text { and traditional cigarettes, and } 6.8 \text { times } \\
\text { more likely among people who smoke } \\
\text { both types of cigarettes in the last } 30 \\
\text { days / } \\
\text { - zachorowanie na COVID-19 jest } \\
5 \text { razy bardziej prawdopodobne w } \\
\text { grupie osób kiedykolwiek używających } \\
\text { tylko e-papierosów, } 7 \text { razy bardziej } \\
\text { prawdopodobne wśród kiedykolwiek } \\
\text { palących e-papierosy i papierosy } \\
\text { tradycyjne oraz } 6,8 \text { razy bardziej } \\
\text { prawdopodobne wśród palących oba } \\
\text { rodzaje papierosów w ostatnich } 30 \\
\text { dniach, }\end{array}$ & $\begin{array}{l}\text { - the incidence of } \\
\text { COVID-19 is associated } \\
\text { with the use of only } \\
\text { e-cigarettes by adolescents } \\
\text { and the simultaneous use of } \\
\text { e-cigarettes and cigarettes / } \\
\text { - zachorowalność na } \\
\text { COVID-19 wiąże się z } \\
\text { używaniem przez młodzież } \\
\text { wyłącznie e-papierosów } \\
\text { oraz jednoczesnego } \\
\text { używania e-papierosów i } \\
\text { papierosów }\end{array}$ \\
\hline $\begin{array}{l}\text { Lee A.C. } \\
\text { et al. }\end{array}$ & $\begin{array}{c}\text { observational } \\
\text { study / } \\
\text { badanie } \\
\text { obserwacyjne }\end{array}$ & USA & $\begin{array}{c}\text { not applicable / } \\
\text { nie dotyczy }\end{array}$ & $\begin{array}{l}\text { - elevated levels of CD4 T cells in } \\
\text { current tobacco smokers can lead to } \\
\text { increased levels of pro-inflammatory } \\
\text { cytokines, making tobacco smokers } \\
\text { more susceptible to an aggressive } \\
\text { immune response } \\
\text { - in users of e-cigarettes without } \\
\text { nicotine and without flavor, no } \\
\text { significant dysregulation of cytokines } \\
\text { was found (only interferon alfa-8 was } \\
\text { significantly increased) / } \\
\text { - podwyższony poziom limfocytów } \\
\text { T CD4 u obecnych palaczy tytoniu } \\
\text { może prowadzić do podniesienia } \\
\text { poziomu cytokin prozapalnych, } \\
\text { czyniąc palaczy tytoniu bardziej } \\
\text { podatnymi na agresywną odpowiedź } \\
\text { immunologiczną,- u użytkowników } \\
\text { e-papierosów bez nikotyny i bez } \\
\text { aromatu nie stwierdzono znaczącego } \\
\text { rozregulowania cytokin (odnotowano } \\
\text { znacząco podniesiony poziom tylko } \\
\text { interferonu alfa-8) }\end{array}$ & $\begin{array}{l}\text { - using tobacco and flavored } \\
\text { or nicotine-containing } \\
\text { e-cigarettes can lead to an } \\
\text { increased inflammatory } \\
\text { response, but only tobacco } \\
\text { increases ACE2 activity } \\
\text { - smoking traditional and } \\
\text { electronic cigarettes can } \\
\text { increase the susceptibility to } \\
\text { COVID-19 / } \\
\text { - używanie tytoniu i } \\
\text { aromatyzowanych lub } \\
\text { zawierających nikotynę } \\
\text { e-papierosów może } \\
\text { prowadzić do zwiększonej } \\
\text { odpowiedzi zapalnej, } \\
\text { ale tylko tytoń zwiększa } \\
\text { aktywność ACE2- palenie } \\
\text { papierosów tradycyjnych } \\
\text { i elektronicznych może } \\
\text { zwiększyć podatność na } \\
\text { zachorowanie na COVID-19 }\end{array}$ \\
\hline
\end{tabular}

results showed promising trend nicotine/caffeine bonding to the ACE2 receptor, which may block this receptor and prevent SARS-CoV-2 from entering the host cells. Furthermore, the mole ratio of caffeine and nicotine from 6LZG and 6VWF (two key active sites of the SARS-CoV-2 protein S) has a significant impact on the blocking of the ACE2 receptor. The authors also pointed to the possibility of using a combination of nicotine and favipiravir in blocking 6LZG (28).

Interestingly, nicotine might counteract some of the neurological effects of COVID-19 through its anti-
SARS-CoV-2. Wykorzystanie nikotynowych produktów farmaceutycznych, takich jak plastry nikotynowe, gumy czy inhalatory jako konkurencyjnych agonistów dla nAChRs może przywrócić upośledzoną funkcję nikotynowego cholinergicznego systemu oraz prawdopodobnie złagodzić burzę cytokin skuteczniej niż podczas użycia środków hamujących pojedyncze cytokiny (6). Nikotyna hamuje cytokiny prozapalne, takie jak TNF, IL-1, IL-6 i HMGB1, które będąc podwyższone wśród pacjentów z COVID-19, wywołują burzę cytokinową. Może to prowadzić do zespołu ostrej niewydolności oddechowej (ARDS) i niewydolności wielonarządowej 
inflammatory, neuroprotective, and mood-boosting properties (20).

\section{CONCLUSIONS}

Some studies have shown smoking as a risk factor for infection with the new coronavirus and a more severe course of COVID-19. Other studies indicated a reduced number of smokers among people hospitalized for COVID-19 compared to the prevalence of smoking in the studied populations. Researchers do not recommend smoking as a tool to fight the pandemic and show the importance of fighting addiction to reduce the adverse health effects of smoking. They also indicate the harmfulness of devices often used as a replacement for traditional cigarettes to fight addiction - e-cigarettes, IQOS, and waterpipe. Studies inform about the possibility of a protective effect of nicotine by reducing the penetration of the SARS$\mathrm{CoV}-2$ virus into human cells through ACE2 receptors and by weakening the mechanism of a cytokine storm. Both the relationship between the use of nicotine and the morbidity and severity of COVID-19, as well as the possibility of using nicotine in the treatment of the new disease require further in-depth analyzes. Claims about the protective effect of nicotine must be handled with special care by both healthcare professionals and the general public.

\section{REFERENCES}

1. Brake SJ, Barnsley K, Lu W, et al. Smoking upregulates angiotensin-converting enzyme-2 receptor: A potential adhesion site for novel coronavirus SARS-CoV-2 (Covid-19). J Clin Med 2020; 9(3):841.

2. Münzel T, Hahad O, Kuntic M, et al. Effects of tobacco cigarettes, e-cigarettes, and waterpipe smoking on endothelial function and clinical outcomes. Eur Heart J 2020;41(41):4057-4070

3. Archie SR, Cucullo L. Cerebrovascular and neurological dysfunction under the threat of COVID-19: Is there a comorbid role for smoking and vaping? Int J Mol Sci 2020; 21(11):3916.

4. Simons D, Shahab L, Brown J, Perski O. The association of smoking status with SARS-CoV-2 infection, hospitalisation and mortality from COVID-19: a living rapid evidence review with Bayesian meta-analyses (version 7). Addiction 2020; Epub ahead of print.

5. Kashyap VK, Dhasmana A, Massey A, et al. Smoking and COVID-19: adding fuel to the flame. Int J Mol Sci 2020;21(18):6581.

6. Gonzalez-Rubio J, Navarro-Lopez C, LopezNajera E, et al. Cytokine release syndrome (CRS)
$(5,21,22)$. Podkreślono, że palenie nie może być wykorzystane do zapobiegania zakażeniom wirusem SARS-CoV-2, jednak niezwykle ważne wydaje się dalsze badanie funkcji nikotyny w przywróceniu funkcjonowania cholinergicznego układu przeciwzapalnego oraz w walce z pandemią COVID-19 (21).

Mohammadi wraz z współpracownikami zbadał interakcje między nikotyną i kofeiną a ludzkim ACE2 receptorem białka S wirusa SARS-CoV-2, używając do tego symulacji dynamiki molekularnej. Wyniki symulacji ukazały obiecującą tendencję wiązania nikotyny/kofeiny z receptorem ACE2, co może powodować blokadę tego receptora i uniemożliwiać wnikanie SARS-CoV-2 do komórek gospodarza. Ponadto stosunek molowy kofeiny i nikotyny z 6LZG i 6VWF (dwoma kluczowymi miejscami aktywnymi białka S wirusa SARS-CoV-2) również ma duży wpływ na blokadę receptora ACE2. Autorzy wskazali także na możliwość skutecznego wykorzystania połączenia nikotyny i fawipirawiru w blokowaniu 6LZG (28).

Co ciekawe, nikotyna ze względu na swoje właściwości przeciwzapalne, neuroprotekcyjne i poprawiające nastrój, może przeciwdziałać niektórym neurologicznym skutkom COVID-19 (20).

\section{WNIOSKI}

Część badań ukazało palenie tytoniu jako czynnik ryzyka zakażenia nowym koronawirusem oraz cięższego przebiegu COVID-19. Inne badania z kolei wskazały na zmniejszoną liczbę palaczy wśród osób hospitalizowanych z powodu COVID-19 w stosunku do rozpowszechnienia palenia $\mathrm{w}$ badanych populacjach. Badacze zgodnie nie zalecają palenia jako narzędzia do walki z pandemią i ukazują istotę walki z nałogiem w celu zmniejszenia niepożądanych skutków zdrowotnych palenia. Wskazują również na szkodliwość urządzeń używanych często jako zamiennik papierosów tradycyjnych do walki z nałogiem - e-papierosów, IQOS oraz fajki wodnej. Badania informują o możliwości ochronnego działania nikotyny poprzez zmniejszenie wnikania wirusa SARS-CoV-2 do komórek ludzkich przez receptory ACE2 oraz osłabienie mechanizmu burzy cytokinowej. Zarówno zależność między stosowaniem nikotyny a zachorowalnością i ciężkością przebiegu COVID-19, jak i możliwości wykorzystania nikotyny w leczeniu nowej choroby, wymagają dalszych pogłębionych analiz. Twierdzenia o działaniu ochronnym nikotyny muszą być traktowane ze szczególną ostrożnością zarówno przez personel medyczny, jak i ogół populacji. 
and nicotine in COVID-19 patients: trying to calm the storm. Front Immunol 2020;11:1359.

7. Meini S, Fortini A, Andreini R, et al. The paradox of the low prevalence of current smokers among Covid-19 patients hospitalized in non-intensive care wards: results from an Italian multicenter case-control study. Nicotine Tob Res 2020; Epub ahead of print

8. Tsigaris $\mathrm{P}$, Teixeira da Silva JA. Smoking prevalence and COVID-19 in Europe. Nicotine Tob Res 2020;22(9):1646-1649.

9. Farsalinos K, Barbouni A, Poulas K, et al. Current smoking, former smoking, and adverse outcome among hospitalized COVID-19 patients: a systematic review and meta-analysis. Ther Adv Chronic Dis 2020;11:2040622320935765.

10. González-Rubio J, Navarro-López C, López-Nájera E, et al. A systematic review and meta-analysis of hospitalised current smokers and COVID-19. Int J Environ Res Public Health 2020;17(20):7394.

11. Sanchez-Ramirez DC, Mackey D. Underlying respiratory diseases, specifically COPD, and smoking are associated with severe COVID-19 outcomes: a systematic review and meta-analysis. Respir Med 2020;171:106096.

12. Alqahtani JS, Oyelade T, Aldhahir AM, et al. Prevalence, severity and mortality associated with COPD and smoking in patients with COVID-19: a rapid systematic review and meta-analysis. PLoS One 2020;15(5):e0233147.

13. Tattan-Birch H, Perski O, Jackson $S$, et al. COVID-19, smoking, vaping and quitting: a representative population survey in England. Addiction 2020; Epub ahead of print.

14. Jackson SE, Brown J, Shahab L, et al. COVID-19, smoking and inequalities: a study of 53002 adults in the UK. Tob Control 2020;2020-055933. Epub ahead of print.

15. Reddy RK, Charles WN, Sklavounos A, et al. The effect of smoking on COVID-19 severity: a systematic review and meta-analysis. J Med Virol 2021 Feb;93(2):1045-1056.

16. Gülsen A, Yigitbas BA, Uslu B, et al. The effect of smoking on COVID-19 symptom severity: systematic review and meta-analysis. Pulm Med 2020;2020:7590207.

17. Patanavanich R, Glantz SA. Smoking is associated with COVID-19 progression: a meta-analysis. Nicotine Tob Res 2020;22(9):1653-1656.

18. Usman MS, Siddiqi TJ, Khan MS, et al. Is there a smoker's paradox in COVID-19? BMJ Evid Based Med 2020;bmjebm-2020-111492. Epub ahead of print.

19. Farsalinos K, Eliopoulos E, Leonidas DD, et al. Nicotinic cholinergic system and COVID-19: in silico identification of an interaction between
SARS-CoV-2 and nicotinic receptors with potential therapeutic targeting implications. Int $\mathrm{J}$ Mol Sci 2020; 21(16):5807.

20. Tizabi Y, Getachew B, Copeland RL, et al. Nicotine and the nicotinic cholinergic system in COVID-19. FEBS J 2020;287(17):3656-3663.

21. Panoutsopoulos AA. Known drugs and small molecules in the battle for COVID-19 treatment. Genes Dis 2020;7(4): 528-534.

22. Voinsky I, Gurwitz D. Smoking and COVID-19: Similar bronchial ACE2 and TMPRSS2 expression and higher TMPRSS4 expression in current versus never smokers. Drug Dev Res 2020;10.1002/ ddr.21729. Epub ahead of print.

23. Smith JC, Sausville EL, Girish V, et al. Cigarette smoke exposure and inflammatory signaling increase the expression of the SARS-CoV-2 receptor ACE2 in the respiratory tract. Dev Cell 2020;53(5):514-529.e3.

24. Chakladar J, Shende N, Li WT, et al. Smokingmediated upregulation of the androgen pathway leads to increased SARS-CoV-2 susceptibility. Int J Mol Sci 2020; 21(10):3627.

25. Pino LE, Triana I, Pérez C, et al. Electronic nicotine delivery systems (ECs) and COVID-19: the perfect storm for young consumers. Clin Transl Oncol 2020;1-5.

26. Gaiha SM, Cheng J, Halpern-Felsher B. Association between youth smoking, electronic cigarette use, and COVID-19. J Adolesc Health. 2020;67(4):519523.

27. Lee AC, Chakladar J, Li WT, et al. Tobacco, but not nicotine and flavor-less electronic cigarettes, induces ACE2 and immune dysregulation. Int $\mathrm{J}$ Mol Sci 2020; 21(15):5513.

28. Mohammadi S, Heidarizadeh M, Entesari M, et al. In silico investigation on the inhibiting role of nicotine/caffeine by blocking the $\mathrm{S}$ protein of SARS-CoV-2 versus ACE2 receptor. Microorganisms 2020;8(10):1600.

Received: 16.12 .2020

Orzymano: 16.12.2020 r.

Accepted for publication: 13.04.2021

Zaakceptowano do ruku: 13.04.2021 r.

\section{Address for correspondence: \\ Adres do korespondencji:}

Anna Korzeniowska

Chair and Department of Epidemiology and Clinical

Research Methodology

Medical University of Lublin

Radziwiłłowska 11, 20-080 Lublin, Poland

tel. 814486370

e-mail: akorz9607@gmail.com 